\title{
A „Sárga zongoraszoba”. Rippl-Rónai zenei festészete
}

\author{
MEGYERY NOÉMI \\ Petőfi Irodalmi Múzeum - Országos Színháztörténeti Múzeum és Intézet \\ 1013 Budapest, Krisztina krt. 57., e-mail: megyerynoemi@gmail.com
}

\begin{abstract}
MegYeRY, N.: „The Yellow Piano-Room”. The musical painting of Rippl-Rónai.

Abstract: The 1910's brought about the appearance of a number of pieces with the subject of music in Rippl's oeuvre, which do not exhibit French impact from the perspective of painting only, but with regards to the approach to musical topics and music in general as well. The aforementioned pieces lend themselves to be observed from a new angle when considering the change of attitude which has developed in the areas of painting and music in the $19^{\text {th }}$ century, and which influenced the approach of certain French circles towards music and so the approach of the Hungarian painter who used to foster active relations with these circles. Through the example of The Yellow Piano-Room, I wish to present with the emphasis placed on the Róma-ville era - the way how the French interest towards music perceived by the painter in Paris during the 1890's, has gained new and unique shape in his art in the 1910's.
\end{abstract}

Keywords: Nabis, Kaposvár, Róma-ville, absorption, instrument, nocturne, picturing listening

\section{Bevezetés}

Mivel a Rippl-Rónai Józsefröl szóló irodalom olyan bőséges, hogy ahhoz hozzátenni már nem egyszerü feladat, én egy olyan oldalról közelíteném meg az ő müvészetét, ahonnan eddig csak kevés figyelem érte. $\mathrm{Az}$ eddigi kutatás igencsak alulértékelte azt, hogy Rippl-Rónai számára a zene milyen fontossággal bírt, valamint művészetében mennyiben tekinthető inspirációs forrásnak. Pedig franciaországi évei alatt egy olyan kör tagja volt, ahol a zenének kitüntetett szerepe volt, s a képzőművészek szándékosan keresték a kapcsolódási pontokat a zenével. Ennélfogva szeretném feltárni, hogy Rippl-Rónai számára a zene milyen fontossággal bírt, valamint hogy ezen a területen milyen ízlésformáló szerepet játszottak azok a francia körök, elsősorban a Nabik, akikkel párizsi évei alatt szoros kapcsolatban állt. A zene fontosságát nemcsak életrajzi adatok, a festő önvallomásai, valamint barátai feljegyzései támasztják alá, hanem azok a magánéleti szálak és kulturális kapcsolatok is, amelyekre eddig ilyen aspektusból nem sok figyelem irányult. A zenével kapcsolatos francia hatás mértékét pedig Rippl-Rónai zenei témájú művein keresztül kívánom bemutatni. Főként az 1910-es években érhető tetten ez az érdeklödés, ezért a hangsúlyt e korszakára helyezném, mivel ebben az időszakban váratlanul megnőtt munkásságában a zenei témájú müvek száma. Ennek okait, belső indítékait, esetleges korábbi hatások megnyilvánulásait - így az előzményeket is - kutatom, valamint, hogy az 1890-es évek Párizsában tapasztalt zene iránti érdeklődés hogyan öltött új formát az 1910-es Róma-villa-beli években.

Habár a magyar szakirodalom nagy figyelmet fordít Rippl-Rónai Nabikkal való kapcsolatára, mégis ritkán vagy csak kevés szóban kerül elő e köröknek az ilyen irányú feltárása, s zenei érdeklődésük megnyilvánulásainak a magyar festöre gyakorolt esetleges hatása. E tanulmány célja továbbá, hogy felvázolja annak az ízlés- és szemléletváltozásnak az ívét, amely Munkácsytól a Róma-villáig terjedő időszakban mind festészeti, mind zenei téren egyaránt érinti Rippl-Rónait, hogy ezáltal még teljesebb képet kapjunk alkotói felfogásáról, elhelyezve azt a megfelelő kulturális kontextusban.

\section{Rippl-Rónai útja a Nabikig}

Rippl-Rónai zenére való fogékonysága nem a párizsi művészkörök hatására alakulhatott ki, ezen érdeklődésének jó alapot biztosíthatott családi háttere, ahol a zene erősen jelen volt. A Rippl fiúk nagy valószínüséggel részesülhettek valamilyen szintü zenei nevelésben is, ugyanis négyük közül a legfiatalabb, Sándor, hivatalosan is zenei pályára lépett, s az Operaház énekeseként kamatoztatta tehetségét. ${ }^{1} A$ többi fiúnak is lehetett affinitása a zenéhez, mindnyájuk számára a hétköznapi élet szerves része lehetett a muzsika. Ezt hivatott bizonyítani az is, hogy a festő Lajos öccse amatőr hegedüsként negyven éven át hangot is adott effajta igényeinek. ${ }^{2}$ Míg a zenétől legtávolabb Ödön állt, a festő Józsefről köztudott, hogy zeneszerető emberként szívesen énekelt és zongorázni is tudott.

Rippl-Rónainak az a vonzalma, amely a zenéhez füzte, abból is világosan kivehető, hogy Emlékezéseiben sok helyen felemlít olyan kis történeteket, melyek a zenével kapcsolatosak. Ez az írása, amelyben sokszor életére vonatkozó lényeges momentumokat nem emel ki, ellenben terjedelmesen és nagy élvezettel ír apró kis részletekről, benyomásokról egy-egy személlyel vagy olykor akár lényegtelennek tűnő - eseményekkel kapcsolatban, megmutat valamit a festő személyiségéből. Lényeges információkat szürhetünk ki abból, hogy húsz év távlatában milyen emlékek foglalkoztatják a festőt, kik azok a személyek, akikre szívesen emlékezik. Ezeknek sorában gyakran előkerülnek ma már ismeretlen-

1 Horváth J. 2007, 17.

2 Lajos zenei kötődéséről árulkodik az Apám és Lajos öcsém (1906) címü festmény, melyröl azonban e dolgozat keretein belül nem kívánok szólni. Ld. Rippl 1998, Kat. 82. 
nek tűnő zenésznevek is, akiket Rippl párizsi társasága szerves alkotóegységeiként említ. ${ }^{3}$ A különböző események kapcsán megmaradt muzsikusnevek azt sejtetik, hogy ezekre a személyekre is felfigyelt egy-egy látogatás vagy barátaival való találkozás alkalmával. ${ }^{4}$ Bizonyosan meghatározó az a környezet, amelyben találkozott velük, illetve az ilyen emlékek mögött ott állhat a müvészetnek azon ága iránti érdeklődése is, amelyet ezek a személyek képviseltek. Sok esetben a felmerülő nevekröl ma igen csak kevés információnk van, így a további kutatás feladata meghatározni e személyek kilétét s kapcsolatuk minőségét a festővel.

\section{Zenei élet Munkácsynál}

Rippl első zenei emlékei a Munkácsynál töltött időszak kapcsán kerülnek elö, ahonnan több ilyen pillanatot említ. A fiatal festő Párizsba kerülvén Munkácsy pártfogásában hivatalos volt a mester pénteki estélyeire, ahol az előkelő társaság tagjai közt feltűntek nagy zeneszerzők és zenészek is, $s$ ahol ilyenformán mindig szólt a muzsika. Ezeknek az estélyeknek olyan múltja volt, hogy pár évvel korábban tolongtak a látogatók, hogy hallhassák zongorázni a még élő, idős Liszt Ferencet. ${ }^{5}$ Maga Rippl is megemlíti Emlékezéseiben a zongorát, amelyen a mester játszott: „Itt volt az a zongora, melyen Liszt és Ambrois Thomas sokat játszottak. E mellett énekelt egyik estélyen a kis Komáromi Mariska, aki abban az időben az Operához készült és Párizsban tanult énekelni. Mignonját énekelte Ambrois Thomasnak, aki ez estélyen maga kísérte a zongorán a fiatal magyar énekesnőt." Ambroise Thomas (1811-1896) operaszerző, a párizsi Konzervatórium igazgatójaként a hivatalos müvészeti körök megbecsült tagja volt, aki minden erejével igyekezett az egyre terjedő wagneri elveket visszaszorítani, s idegenkedett az eredetiségre törekvő, haladó szellemű, új zeneszerző generációtól is. ${ }^{7}$ „És sokat hallottam arról is, hogy azelőtt, élete fogytáig, Liszt Ferenc is sokszor megfordult a mester házánál. Hubay is nem egyszer hegedült az estélyeken, amelyek igazán szépek voltak." "Az ebben az időben Budapestről gyakran Párizsba látogató nagyhírü hegedűművész és zeneszerző, Hubay Jenő pedig már évek óta szoros kapcsolatban állt a Munkácsy házaspárral, így estélyeik kedvelt fellépője volt. ${ }^{9}$

Maga Rippl is eleinte gyakran ebédelt és bálozott pártfogójánál, s meglehetősen sok emléket idéz fel a Munkácsynál eltöltött időszakról, valamint azokról az emberekről, akik gyakran a mester vendégei voltak akár Colpachon, akár a párizsi estéken. Az amerikai

3 Ld. Emlékezések 1957, 101.

4 Rippl minden enteriört alaposan szemügyre vett. Ez igaz a Gauguin mütermében tett látogatásra is, ahol a más müvészeti ágak képviselöit is név szerint megjegyezte: „Benyitva a müterembe, homályos világításban több emberi alakot láttam. Egy göndör hajú ember zongorázott: ez Leclerque volt. Egy másik, hosszú hajú, a padlón feküdt: ez Ruinard, a költő...” Emlékezések 1957, 55-56.

5 A Munkácsy „szalonnal” kapcsolatban Id. Boros J. 2005, 50-52.

6 Emlékezések 1957, 43.

7 Brockhaus Riemann 1985, 512

8 Uo. 46-47.

9 Halmy F. és Zipernovszky M. 1976, 64. milliomosok között nem egy zenészt találunk, így például az amerikai magyar muzsikust, Korbayt, feleségével együtt. Korbaynéről emlékezik meg a festő az egyik vacsora kapcsán, hogy a ráktisztogatásban neki nyújtott segítségért „nem egyszer „fizetett vissza” az asszonyság szép zongorajátékával”. ${ }^{10}$ Továbbá említi, hogy mestere mennyire szerette a magyar zenét, $s$ gyakran rendezett „gulyásvacsorákat”, melyekre a fiatal Rippl is hivatalos volt. A magyar vendégsereg élén Munkácsy „ilyenkor volt aztán csak igazi jó magyar ember: rendkívül kedves tudott lenni, eldalolgatott, elelfütyülte kedves nótáit. S ha már előbb is a természet adománya volt, hogy Munkácsy gyönyörüen tudott fütyülni, most már - az idők jele lehetett - kelleténél többet és szebben fütyörészett”. Egy másik estélyröl pedig úgy számol be, hogy „ezen az estélyen volt talán a legjobb kedvében Munkácsy, nemcsak fütyült, hanem még a csárdást is legényesen, peckesen járta".11

Munkácsyék zenei ízlése és zenehallgatási attitűdje kirajzolódik a fenti nevek mentén, amiböl arra következtethetünk, hogy a zene egy könnyedebb szórakoztatási céllal bírt. Wagnert e kör müvészei elutasították, s ezzel azt a zenehallgatási attitüdöt is, amelyet az ő zenéje hozott magával, s amelyről a későbbiekben lesz szó.

\section{A Nabik előtt}

A Munkácsytól való elszakadással Rippl megkezdte saját útját. Későbbi feleségével, Lazarine Boudrilonnal és nála gazdagabb skót barátjával, James Pitcairn Knowles-szal közös házba költözött Neuilly-ben. A neuillyi időszakra eső „fekete korszak” képein az enteriőr egyre gyakrabban festett témájává válik, a „csendes”, cselekménymentes intim otthon, melyröl egyfajta állapotképet ad.

Rippl szerette a társasági életet, sokféle helyre eljárt, színházba, kávéházakba, lóversenyre s barátainak mütermeibe. ${ }^{12}$ Ilyen látogatásai kapcsán gyakran megemlékezik az enteriőrről, a mütermek berendezéséről s az ott jelenlévő személyekről. Rippl-Rónai, akárcsak Vuillard, gyakran készített fotókat is környezetéről, melyeket aztán felhasználhatott műveihez is. ${ }^{13}$ Habár az enteriőr téma már ekkor izgatta Ripplt, mégis kevés képe van, amelyen saját neuillyi otthonának tereit örökítette meg. Ugyan több fotót készített a közös lakásról, festményei közül csak az Alkonyat egy intim szobában (1892) (1. ábra) címü az, amelyen dokumentálta akkori életének színterét. Később, anyjához írott leveleiben folytatásosan közli lakása berendezésének leírását, ${ }^{14}$ ez a festménye azonban a berendezésnek egy korábbi, szerényebb állapotát tükrözi, közvetlenül a költözés utáni időből. Ez a festmény különös figyelmet érdemel, hiszen ezen jelenik meg először olyan utalás, amely a festő zene iránti érzékenységére vall. Érdekes, hogy habár a beren-

\footnotetext{
10 Emlékezések 1957, 38

11 Emlékezések 1957, 47

12 Keserü K. 2004, 21

13 E. Csorba Cs. 1998, 185-199.

14 Rippl-Rónai levelei anyjához (Neuilly, 1895. nov. 10; 1895. nov. 24.) MTA MKCS-C-I-36/367-368
} 


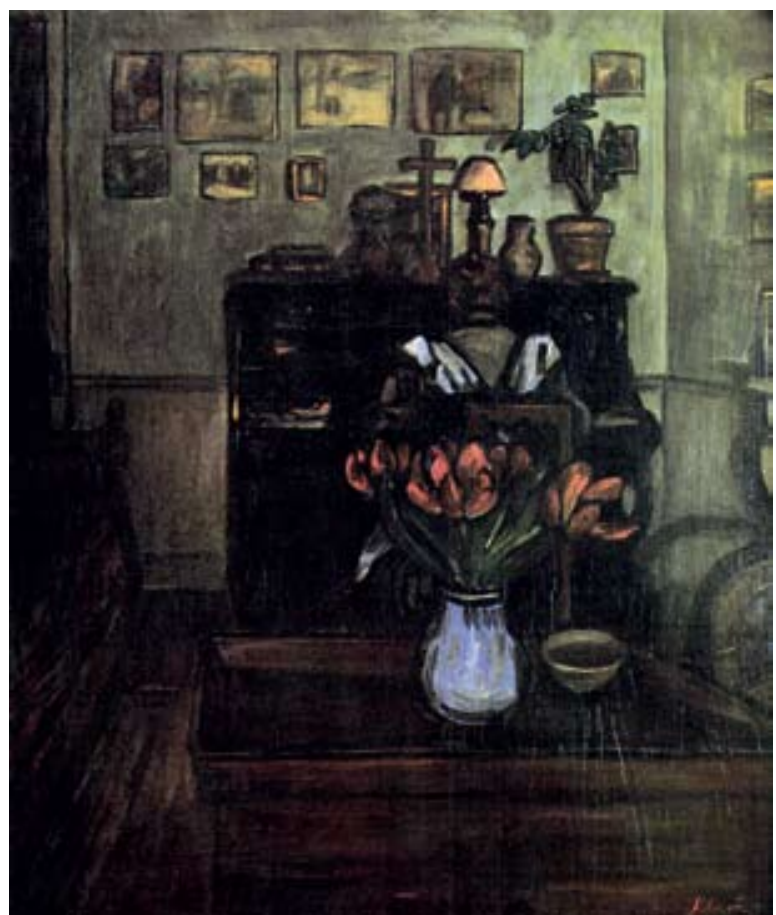

1. ábra. Rippl-Rónai József: Alkonyat egy intim szobában, 1892. Olaj, vászon; 65 × 54 cm; Pécs, Janus Pannonius Múzeum, Ltsz. 68. 166.

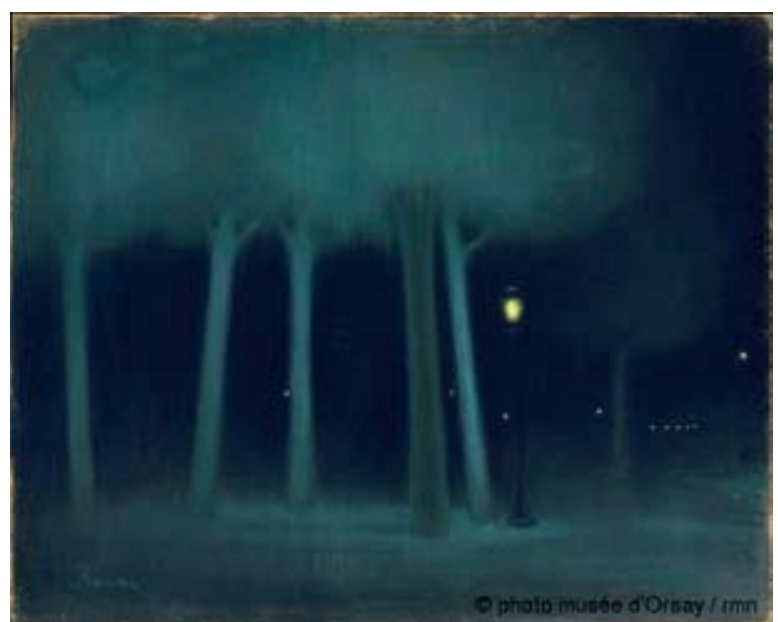

2. ábra. Rippl-Rónai József: Park éjszaka, 1892 körül. Pasztell, papír, vászonra kasírozva; 38, 4 x 46,2 cm; Musée d'Orsay, Párizs, Ltsz. RF 43398

dezés még szegényes, a pianínó már akkor ott állt a szobában, mely nagy valószínüséggel a módosabb lakótárs, Knowles ajándékaként került a lakásba. ${ }^{15}$ A festő feltehetően büszke lehetett a tulajdonában lévő zongorára, amely valóban nemcsak bútordarabként kapott helyet szerény lakásában. „Ha üres időm akad, napjában többször is zongorálok (mert van zongoránk is csak néhány jó magyar nóta és szép keringő hiányzik). Most egyelöre abban a szobában van ez, a hol

15 Rippl 1998, 242. ezt a levelet irom és a hol enni szoktunk, Olyan szép ez a szoba, mint egy jól gondozott falusi kápolna."16

$\mathrm{Az}$ enteriőrt a falon látható képek teszik személyessé, valamint maga Lazarine, aki a zongoránál ül. Ő azonban nem vonja el a figyelmünket arról, hogy mi a kép valódi témája, mivel nem az ő cselekvése, a zongorázás van a középpontban. Erre utal a beállítás: Lazarine háttal ül, s első látásra észre sem vennénk őt, ha a festő nem emelte volna ki a szürkék és feketék foltjából ruhájának kék kötényét, s zongorázó bal kezét. Ennek a zongorázó kéznek a hangsúlyozása emeli ki a képet annak mozdulatlanságából és csendjéből, s enged ráismerni arra, hogy a zene jelenléte igenis erős, s az állapotleíráshoz szorosan hozzátartozik. Az előtérben elhelyezett kék váza és a narancsos árnyalatú virágok vezetik végig a néző tekintetét a kép terének mélyébe, ahol az erre rímelő ruha és kéz kiemelik a nőalakot a sötétből. Egyértelműen nem a cselekvés az, amely Ripplt festésre indította, hanem annak a hangulatnak a kifejezése, amelyet ebben a szobában érez, így a belső tér egyben a festő belső világába enged betekintést. Lazarine esetében a zongorázás ugyancsak az ő belső világára mutat rá. Rippl úgy vélte, azzal tudja a legjobban kifejezni, ki is ő, ha azt láttatja, amiben él. ${ }^{17} \mathrm{Ha}$ Rippl enteriőrképein megjelent egy-egy számára kedves személy, akkor mégse az alakra, hanem a környezetre vagy az élethelyzetre utaló címet adott a münek.

Jelen esetben Lazarine zongorázó bal keze utal a zene jelenlétére, csakúgy, mint Fernand Khnopff - csaknem tíz évvel korábbi - Schumann hallgatása közben (1883) (3. ábra) címü képén. A szimbolista Khnopff azonban képe főszereplőjévé a zenét hallgató hölgyet tette meg, így a zongoristára való utalás csak másodlagos, alakja nem is látható, csupán jobb keze a klaviatúrán. $E$ kép valódi témája az az emocionális hatás, amelyet a zene vált ki a hallgatóból. ${ }^{18} \mathrm{~A}$ fiatal hölgy a kép középpontjában karosszékébe roskadva és kezébe temetkezve merül gondolataiba. A melankólia és kontempláció ilyen típusú megjelenítése jól illik a szimbolista művész habitusához. A szimbolisták szerint a kép nem az ábrázolt tárgy vagy személy fizikai voltát akarja a néző elé tárni, hanem annak mögöttes tartalmát kívánja átadni, s a nézőre bízza, hogy számára milyen eszmei értéket közvetít az így keletkezett mü. A festmény tárgya egyfajta jellé válik, aminek jelentése a szemlélés során bomlik ki, mind a festő számára az alkotás előtt, mind a néző számára a kész kép szemlélésekor.

16 Rippl-Rónai levele anyjához (Neuilly, 1895. nov. 10.) MTA MKCSC-I-36/367. Megjelent: Rippl 1998, 495-496.

17 „Az intim életből merítem témáimat, mert ezt az életmódot szeretem és respektálom. Megfestendö tárgyaim kifogyhatatlanok, mert minden érdekel, ami körülvesz és szürke kedélyemre, borongós lelkiállapotomra jótékonyan hat. - Szerintem csak az lehet dokumentuma életünknek, amiben magunk élünk, éppen ezért, szeretem azt megfesteni." Rippl-Rónai Malonyay Dezsőnek. Közölve: Malonyay D. 1906, betétlap

18 Khnopff 2004, 74. (Cat. 10.) 


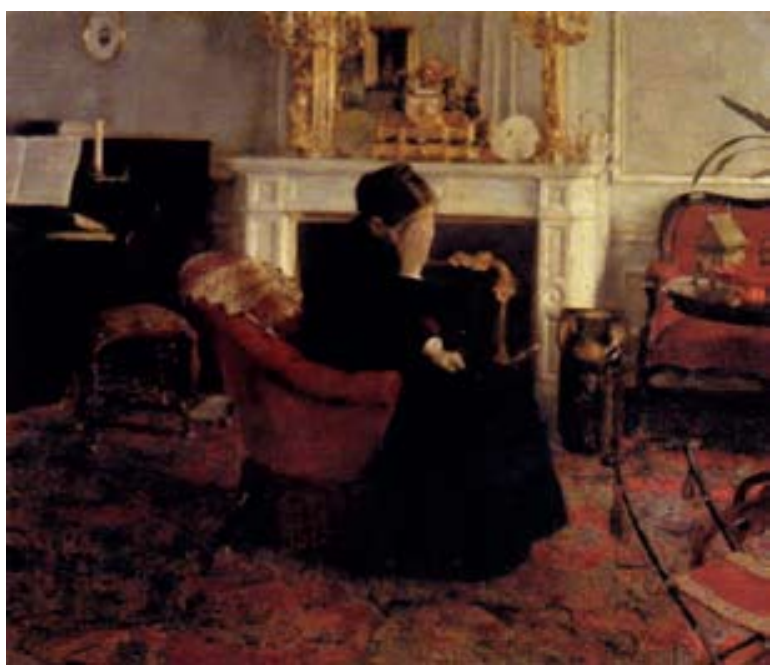

3. ábra. Fernand Khnopff: Schumann hallgatása közben (Un écoutant du Schumann), 1883. Olaj, vászon; 101,5 x 116,5 cm; Musées Royaux des Beaux-Arts de Belgique, Brüsszel, Ltsz. 6366

Ide hozható James Ensor Orosz zenéje is (1881) (4. ábra), melyen a zongorázó nőalak ugyancsak háttal ül a nézőnek. E kép szolgált előképéül a Khnopff festménynek, mely miatt a két művész össze is veszett egymással. ${ }^{19}$ Ensor szintén ráhelyezte a képére a hallgatót - bár még nem ő a kép egyedüli főszereplője, mint Khnopffnál -, s a zongorán látható a kotta, mint a dallamok elsődleges forrása. Továbbá a gazdag enteriőrben különböző üvegtárgyak és egy tükör is helyet kapott, amelyek mind a belső reflexióra, a befelé fordulásra utalnak, tehát egyértelmü, hogy a befogadás képezi a kép témáját. ${ }^{20}$ Rippl-nél azonban nem kapott szerepet sem a hallgató, $\mathrm{s}$ a kottát sem látjuk a zongorán. Véleményem szerint itt Rippl saját maga az, aki a zene elsődleges hallgatója, akiben a dallamok hatására megjelenő érzések egy kép festését eredményezik. Ő azt a hangulatot kívánja megjeleníteni redukált festői eszközökkel, amelyben ő maga részesül. $A z$, hogy nincs szerepe a kottának a zenejátszásban, még személyesebbé teheti a képet, utalva arra, hogy Lazarine emlékezetből játssza a dallamokat, s ezzel is saját ízlését és intim belső világát tárja a néző elé. Bár a kép rajzos dekorativitásában nem rokonítható e két festmény egyikével sem, ebben sokkal közelebb áll a Nabik módszereihez, s elsősorban Vuillard-hoz, habár ez még a Nabikkal való találkozás előtt készült. Ugyanakkor annak ellenére, hogy törekvéseiben rokona kortársainak, mégis egyéni megoldást kínál. ${ }^{21}$

Különleges szimbolizmust eredményez az, hogy nem jeleníti meg a zenét hallgató személyt a képen, akin láthatjuk a zene által kiváltott érzelmeket. A zene az intim szoba alkotóeleme, a dallamok megtöltik

19 Amikor 1886-ban mindkét művet egyidejüleg állították ki a Salon des XX-n, Ensor plagizálással vádolta Khnopff-ot, mely a két müvész tartós konfliktusához vezetett. Vö. Khnopff 2004, 74

20 Leonard, A. 2007, 272.

21 Rippl 1998, 242-243. (Kat. 25.)

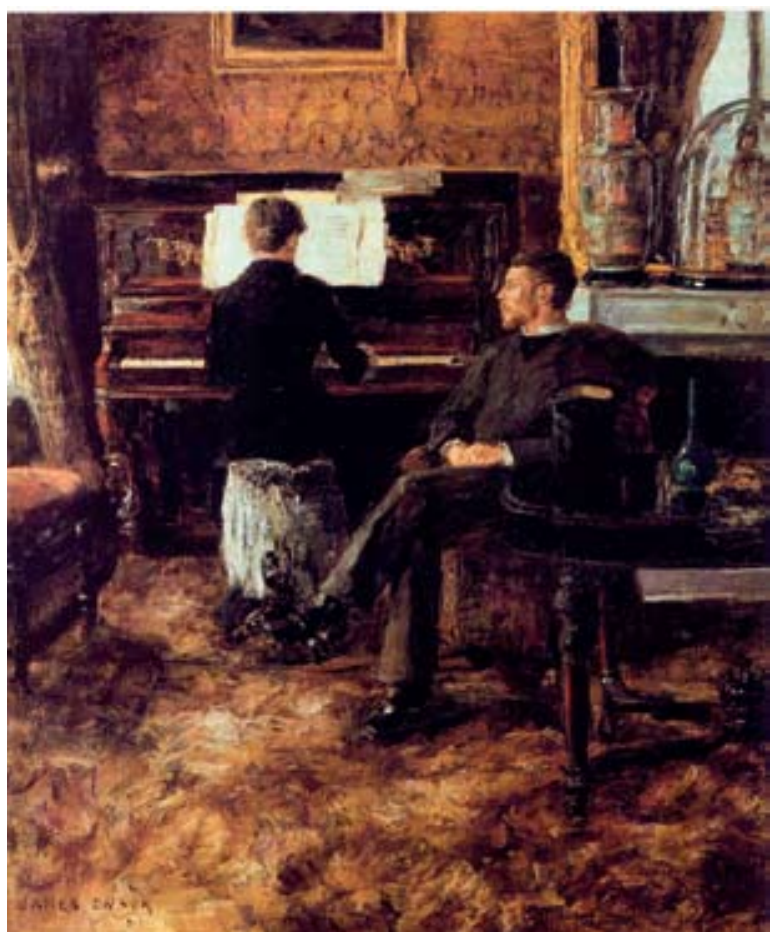

4. ábra. James Ensor: Orosz zene (La musique russe), 1881. Olaj, vászon; 133 × $110 \mathrm{~cm}$; Musées Royaux des Beaux-Arts de Belgique, Brüsszel, Ltsz. 4679

a szobát, s Rippl csupán ezt kívánta megjeleníteni, egyfajta állapotképként, amelybe a néző belehelyezkedhet. Érzések, képi ábrázolás és a zene ilyen öszszeolvadása enged arra következtetni, hogy számára ezek elválaszthatatlanok egymástól. Az első látásra borongós hangulatot árasztó kép ezáltal az otthon melegét és intimitását hozza közelebb, melyhez jól illik az alkonyati megvilágítás. Nem véletlen, hogy a kép címe sem a zenére utal, mint kortársainál, hanem erre az állapotra, melyben az alkonyat is hangsúlyos.

Rippl-Rónai ebben az időszakban kezdett érdeklödni a szürkület, az este, az éjszaka adta fények és atmoszférikus jelenségek hangulata és megfestése iránt. „Szürke azért voltam, mert szürke volt a hangulatom - ezt kerestem szürkületben, hajnalban. Volt idő, mikor csak éjjel éltem - tetszett a kék levegő." ${ }^{22}$ 1892-es első önálló párizsi kiállításán - mely a francia közönség előtt első önálló sikerét hozta meg - több egyéni felfogású tájképet, éjszakai s lámpafény-effektusos képet állított ki. ${ }^{23}$ Ezek nagy részét ma már nem ismerjük, ilyenformán életmúvének ez a területe igencsak kiaknázatlan. A 90-es évek végén Szinyei Merse Anna szentelt némi figyelmet Rippl egy-egy ilyen témájú múvének, s ez igencsak érdekes lehet az Alkonyat egy intim szobában enteriőrjének kapcsán is.

22 Levél Rónai Jánoshoz (1910. okt. 8.) Közli: Szinyei Merse A. 1999, 6

23 Éjjeli témájú műveinek egy szép példája a Park éjszaka (1892 körül) (2. ábra). Ld. Szinyei Merse A. 1998, 55. 
A századvég csaknem minden festőjét megérintette a természet esti megvilágítása és hangulata, s föként Párizsban nagy érdeklődés támadt a nocturne-képek iránt, melyek a szimbolista felhangtól sem mentesek. A francia fővárosba elsőként Whistler hozta be ezt a témát, aki egymás után állította ki intenzív zeneiségü nocturne-képeit. ${ }^{24}$ Whistler, aki előszeretettel adott zenei címeket műveinek, Rippl-Rónai - csakúgy, mint a Nabik - sokat csodált festői közé tartozott. Talán nem véletlen, hogy Rippl is ekkortájt kezdett az ilyen témák iránt érdeklődni, s ez a sötét színeken alapuló kerettéma igencsak passzolhatott fekete korszakának borongós színeihez és ebből kiinduló festői kísérleteihez. ${ }^{25}$

A nocturne képek zeneisége bizonyosan őt is megérintette, s akkori lélekállapotához közelinek érezhette az alkonyat jelenségét. Esténként sokszor dolgozott, s a századfordulón gyakran jelennek meg éjjeli témájú müvek kiállításain. ${ }^{26}$ Rippl-Rónai érezhetett valami zeneiséget az alkonyati - csakúgy, mint az éjjeli - megvilágítás sajátosságában. A nocturne-képekre jellemző zeneiség ragadhatta meg ez alkalommal is, egyúttal az alkonyat adta hangulatban. A zongorázás felerősítheti a zenei asszociációkat, s ezáltal a nocturne képek sorába illeszkedik ez a sajátságos enteriőrkép is. Ily módon összekapcsolja ezt a két kedves témáját, s az esti fények-hangulatok zeneiségét egy intim légkörü témába, az enteriőrbe helyezte.

\section{A zene szerepének megváltozása}

A zene ábrázolásának fenti módjai (Ensor, Khnopff és Rippl képe) egy olyan nagyobb változás részét képezik, amely a században társadalmi és kulturális szinten ment végbe. A 19. században teljesen átalakult a művészeti ágak hierarchiája, melyben a zene érzelmeket kifejező tulajdonsága által a legmagasabb rangra került. A romantika írói rádöbbentek arra, hogy a zene az egyetlen olyan művészeti ág, amely valóban a kifejezésen alapszik, nem pedig az ábrázoláson, az imitáción. ${ }^{27} \mathrm{Az}$ újfajta felfogás társadalmi jelenség is volt, a műveltségre való igény megemelkedésével a koncertlátogatási és zenehallgatási szokások is megváltoztak. Még a 18. században is a zene a társasági élet részét képezte, a szalonokban, koncerteken a nézők hangosan beszélgettek, ettek-ittak, járkáltak, s puszta szórakoztatásként szolgált a háttérben a muzsika. A főúri rezidenciákon a zenészek is az udvartartás „kellékeit” képezték, legtöbbször alkalmazóik igényeire szabott müveket komponáltak, melyek csak egy szűk körben kerültek bemutatásra. A zenészek és zeneszerzők, habár biztosítva voltak életkörülményeik, mégiscsak kiszolgáltatottak voltak. A 19. században terjedtek el azok a zenehallgatási szokások, amelyek lényegüket tekintve ma is érvényben vannak. A muzsika egyszer csak már nem a társasági tevékenység részét

24 Már 1888-tól jelentek meg ilyen témájú művei a párizsi kiállításokon, majd 1892-es Mars-mezei Szalonban öt nocturne képe volt látható. Ld. Szinyei Merse A. 1998, 56.; Szinyei Merse A. 1999, 5-6.

25 Ld. Emlékezések 1957, 60-61.

26 Szinyei Merse A. 1999, 6.

27 Ezt az átalakulást Id. bővebben: Morton M. L. 2000, 1-21. képezte, hanem vallási áhítathoz hasonló méreteket öltött. Mivel a zene hallgatása a transzcendens megtapasztalását rejtette magában, a figyelem elsődlegesen a zenére irányult, $s$ nem volt már helye más cselekvésnek, amíg a mü szólt. A programzenével szemben megjelent az abszolút zene fogalma, amely mindenfajta képtársítástól meg akarja tisztítani a zenét, nehogy az a hallgató figyelmét elvonja. ${ }^{28} \mathrm{Az}$ abszolút zenével szembemenő zeneszerzők a Gesamtkunstwerk megteremtésével a zenét egy intellektuálisabb szintre kívánták emelni, mely Wagnernél minden művészeti ágra kiterjedt, zenedrámáiban a zene, szöveg, díszlet és a mozgás egységével mind az eszmei tartalom és érzelmek kifejezésére törekszik. Wagner művészete és elméleti munkássága Franciaországban is óriási hatással bírt, annak ellenére, hogy a Tannhäuser 1860 -as párizsi előadása nagy ellenállásba ütközött. ${ }^{29}$ Zenéje egy újfajta zenehallgatási attitüdöt követelt meg, amely a hallgató folyamatos koncentrációját igényelte, szemben a könnyed olasz operával. A wagnerizmus igen gyorsan terjedt, s 1885-ben - immár a zeneszerző halála után - érte el csúcspontját. Habár a francia-porosz háború alatt Franciaországban betiltották a szerző zenedrámáinak színpadra állítását, hamarosan zongoraátiratok formájában szólaltatták meg műveit különböző házi szalonokban, mely által a zongorának különös szimbolikus szerepe lett. ${ }^{30}$

\section{Ut pictura musica - A festészet átalakulása}

Ahogy a zenével párhuzamosan a romantika esztétikája a festészetet is átalakította, a tárgy ábrázolása helyett a megfestés hogyanjára került a hangsúly. Így a kép már nem fejthető meg annak olvasása által (az ut pictura poesis elvén) - tehát a mủ témájának megfejtésével, hanem a megfestett tárgy helyett az alkotó belső érzéseire kerül a hangsúly (az ut pictura musica alapján), s annak kifejezésében rejlik a mü valódi értéke.

Habár a zene képes az érzések legtisztább közvetítésére, gyengesége épp abban rejlik, hogy mulandó; a darab elhangzása időbeli történés, s a folyamat egyszer véget ér. Így a festészet - hogy saját határait ne lépje túl, amint azt Lessing Laokoónjában kijelölte ${ }^{31}$ - azt próbálta megragadni, amire a zene nem képes. A kép állandósága képes arra, hogy a zene mulandóságának egy pillanatát maradandóvá tegye, $s$ a festők kísérletezni kezdtek ennek megragadásával. Így a festészet új témára lelt az addig érdektelennek tủnő zenehallgatás témájában. ${ }^{32}$ Mivel maga a zene láthatatlan, a festészet csak a zenei élményt képes megragadni a zenehallgatók vagy zenészek megjelenítésének hogyanján keresztül, mely által kísérletet tesz az elmúló érzések megállítására és az élmény kifejezésére. ${ }^{33}$

$28 \mathrm{Az}$ abszolút zenét Id. bővebben: Brockhaus Riemann (1. kötet) 1983, 13-14.

29 Wagner párizsi fogadtatásáról Id. Baudelaire, Ch. 2001, 81-129.

30 Leonard, A. 2007, 267-269.

31 Ld. Lessing, G. E. 1999, 7-150.

32 Leonard, A. 2007, 266.

33 Vö. Leonard, A. 2007, 266-267. 
A 19. század második felében már Degas korai példáit teremtette meg ennek a hozzáállásnak azokkal a képeivel, amelyekben nem a zenélés tevékenysége, hanem annak befogadása a valódi téma, egyfajta bensőségességre helyezve a hangsúlyt (Manet és felesége, 1868-69; Lorenzo Pagans és Auguste de Gas, 1871-72).

A szimbolizmus korában továbbra is kérdés volt, hogy a vizuális müvészet képes-e a zenei élmény kifejezésére. Mivel a zene egy bensőséges és megfoghatatlan, ábrázolhatatlan dolog, a szimbolisták az emberekből kiváltott érzelmek és belső megmozdulások megragadásában látták annak képi megjelenítési lehetőségét, s a zenehallgatásra koncentrálva a Degas által megkezdett úton haladtak tovább. A legátszellemültebb portrék és a zenésznek a képröl történő teljes kiszorítása után ${ }^{34}$ a század végén Párizsban a Nabik új kifejezési eszközöket kerestek ennek a problémának a megoldására. Maurice Denis a zene-szín kapcsolatát hangsúlyozta 1890-es Définition címü teoretikus müvében. ${ }^{35}$ Ez a szinesztézia iránti érdeklődése elsősorban Wagner és Baudelaire hatásáról árulkodik, akik a szimbolista körök ezen nézeteinek meghatározó forrásai voltak. ${ }^{36}$ A Nabikat általánosságban jellemezte ez a szimbolizmus iránti érdeklődés, amely Párizsban a század végén erősen jelen volt. ${ }^{37}$ Dekorativitásukban a zene egy újfajta kifejezőeszközére leltek, mely igen különböző módon nyilvánult meg az egyes tagoknál. Míg Denis a zene és a színek kölcsönhatását, a szinesztéziát hirdette, addig Bonnard és Vuillard az intim enteriőrökön keresztül a dekorativitás segítségével fejezte ki művein a zenei tartalmat, vagy a zenére való utalást. ${ }^{38}$

\section{A Nabik zenei érdeklődése}

A különböző művészeti ágak egységét hirdető Nabik számára a zene rendkívül fontos volt. Baráti összejöveteleiken a múvészet kérdéseiről vitatkoztak, zenét hallgattak és Baudelaire, Rimbaud, Mallarmé írásaiból olvastak. ${ }^{39}$ Részesei voltak a wagnerizmusnak, rendszeresen látogatták az 1880-as évek végén Lamoureux ${ }^{40}$ Wagner-előadásait - akinek lányával szoros kapcsolatban álltak -, amelyek Párizs kulturális életének nélkülözhetetlen eseményei voltak. ${ }^{41}$ Sérusier - akinek testvére hivatásos zenész volt - különösen muzikális volt, rendszeresen közremüködött barátja, Duteil d'Ozanne kórusában, a Chorale d'Euterpe-ben, csakúgy, mint Paul Ranson felesége, France. Amint d'Ozanne, a ze-

34 Ld. Ensor és Khnopff fentebb említett képeit. Vö. Leonard, A. 2007, 272-276.

35 Ld. Denis, M. 1983, 25-39.; Vaughan, G. 1984, 38.

36 Vaughan, G. 1984, 38-39.

37 Ld. Fréches-Thory C. 1998, 9-16.; Földi E. 2014, 9-75. (55.)

38 Vö. Leonard 2007, 279-280.

39 Gellér K. 1975, 5

40 Charles Lamoureux (1834-1899) francia hegedűművész és karmester, aki 1881-ben saját zenekarával létrehozta a Société des Nouveaux Concerts-t. Ezek a Lamoureux-hangversenyekként emlegetett koncertek nagyban hozzájárultak Wagner népszerüsítéséhez, emlékezetesek a Lohengrin (1887) és a Trisztán (1899) általa vezényelt párizsi előadásai. Brockhaus Riemann (2. kötet) 1984, 382.

41 Vaughan, G. 1984, 40. neszerző Pierre Hermant ugyancsak bekerült körükbe, s mindketten tiszteletbeli Nabikká váltak. ${ }^{42}$

A Nabikat azonban nemcsak munkatársi kapcsolat füzte zenészekhez, zeneszerzőkhöz, szoros barátság, illetve sok esetben rokoni szálak tartották össze az olykor igencsak egymásba fonódó társaságokat. Egyes Nabi múvészek patrónusai álltak egy-egy ilyen társaság élén, amely zenészek, írók és müvészek gyűjtőhelyéül szolgált. Míg Maurice Denis Henry Lerolle-on keresztül került szorosabb kapcsolatba zenészekkel, ${ }^{43}$ addig Bonnard-t családi kötelék füzte a zeneszerző Claude Terrasse-hoz. ${ }^{44}$ Henry Lerolle személye önmagában kifejezte mindazt, amely szalonját jellemezte, lakása írók, festők, műkritikusok és zenészek fontos találkozási helye volt, ahol a müvészetről való gondolkodás és társalgás mellett a zenehallgatás egyaránt nagy szerepet kapott. ${ }^{45}$

\section{Rippl-Rónai és a Revue blanche köre}

Rippl-Rónai szempontjából egy kör érdemel azonban nagyobb figyelmet, ez pedig Thadée Natanson köre, amelynek a magyar festö tagja volt, s amely zenei szempontból is meghatározó lehetett számára. Natanson Vuillard nagy pártfogója volt, de Bonnard is részesült abból a „bűvkörből”, amelyet a Natanson házaspár formált. Thadée az 1891-es első találkozás után hamarosan nemcsak pártfogója és támogatója lett Bonnard-nak és Vuillard-nak, hanem e két festő Natanson és Misia családjának részévé vált. Bonnard és Vuillard az elkövetkezendő tíz évben nemcsak a Revue blanche irodájának lettek törzsvendégei, hanem a lap nem hivatalos „második irodájának is”, amelyet csak „Annex”-ként emlegettek, és amely a Natanson házaspár saját lakását jelentette a rue St.Florentine-en. ${ }^{46} \mathrm{~A}$ lengyel Thadée Natanson 1893-ban vette el feleségül az ugyancsak lengyel származású Misia Godebskát, aki Natanson széles ismeretségi körébe bekerülve hamar annak meghatározó alakjává vált. A művészcsaládból származó Misia kiváló zongorista volt, első nyilvános koncertjét 1892-ben adta. Kimagasló tehetsége ellenére nem kívánta művészi karrierét kiépíteni, helyette csak maga és barátai örömére zongorázott. Natanson révén megismerkedett a Revue blanche összes munkatársával, kritikusokkal, müpár-

\section{Uo., 39, 41}

43 Lerolle mutatta be Maurice Denis-t Debussynek 1893-ban, mely a festő és a zeneszerző komolyabb együttműködésének kezdetét jelentette. Ld. Beyond the easel 2001, 41-42.; Vaughan, G. 1984, 43-44.

44 Terrasse 1890-ben Bonnard húgát (Andrée Bonnard-t) vette feleségül, aki maga is remek zongorista volt. Ld. Bonnard 1984, 72. (Kat. 2.)

$45 \mathrm{Az}$ akadémikus képzettségü Henry Lerolle (1848-1929) festői munkássága és gyüjtői szenvedélye mellett zeneszerzéssel is foglalkozott és elismert amatőr hegedüsként is tevékenykedett. Mivel családjában több zenész is volt, otthonában lehetőséget teremtett zenészek találkozására, s sógora, Ernest Chausson mellett több ismert zeneszerző látogatta szalonját, így Claude Debussy, Paul Dukas és Vincent d'Indy. Lerolle mutatta be Maurice Denis-t Debussynek 1893-ban, mely a festő és a zeneszerző komolyabb együttmüködésének kezdetét jelentette. Henry Lerolle körét Id. bövebben: Beyond the easel 2001, 41-42.; Vaughan, G. 1984, 43-44.; Morehead, A. 2007, 73-81.

46 Beyond the easel 2001, 38-40. 


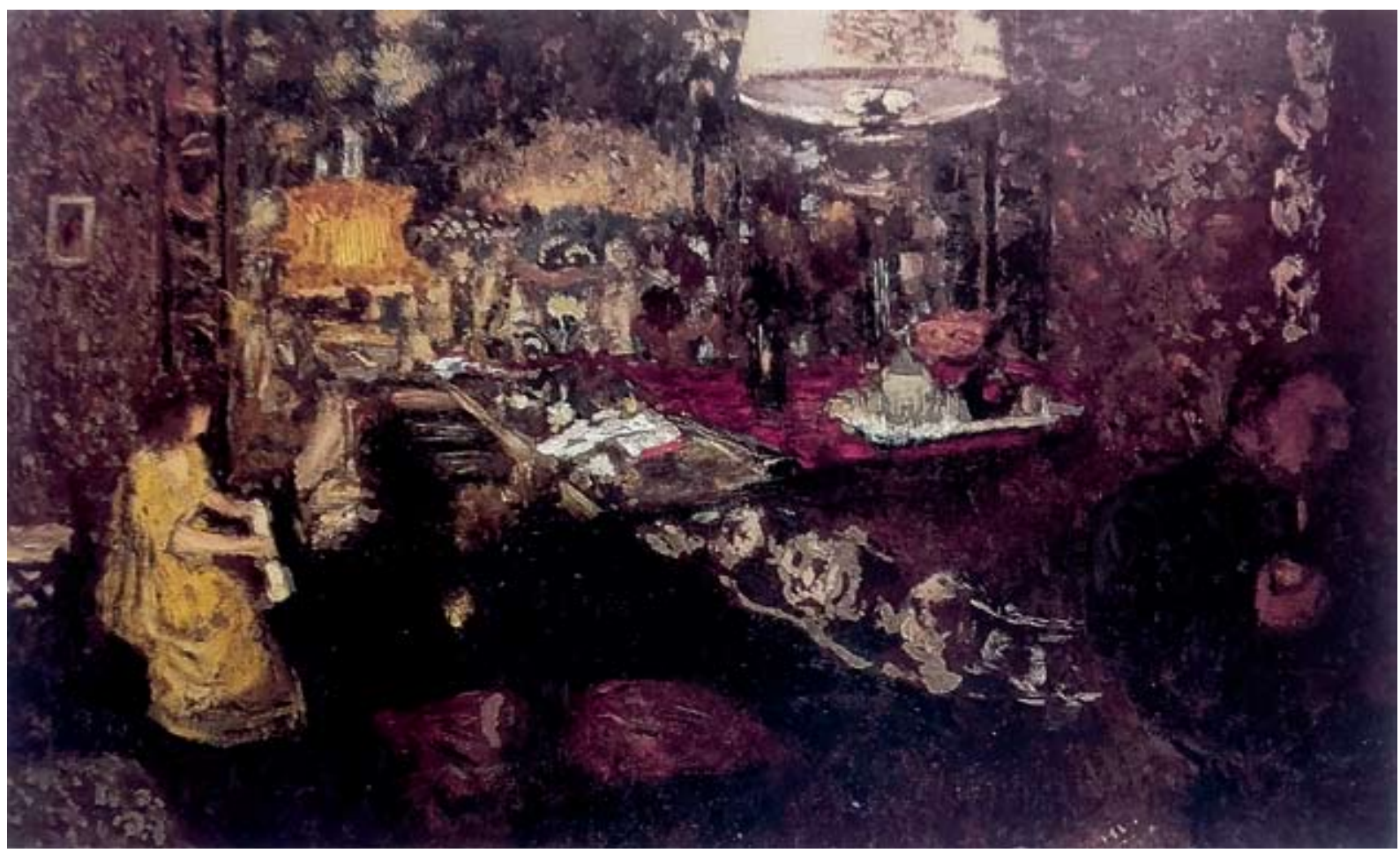

5. ábra. Édouard Vuillard: Misia a zongoránál (Misia au piano), 1899. Olaj, karton; 55 × 80 cm; Magántulajdon

tolókkal, irodalmárokkal, valamint festőkkel, köztük a Nabikkal, ő pedig hozta magával zenészkapcsolatait, valamint egy szorosabb kapcsolódási pontot jelenthetett a Revue blanche köréhez tatozó zeneszerzőkhöz. Személye egy központi szerepet töltött be a Revue blanche mủvészei között, egyszerre támogatója és múzsája lett a Nabiknak is. A róla készült portrék nagy része zongorájánál ülve, barátai társaságában mutatja őt, melyben a legjobban mutatkozik meg az a szerep, amelyet ő a müvészek körében töltött be. Misia nem hozott létre semmit, de azokon az embereken keresztül, akikkel élete során találkozott, s kora müvészeire ható mágneses jelenlétével egyszerre vált múzsává, patrónussá, valamint az ízlés és divat irányítójává. ${ }^{47}$

A Misiáról készült képek (Misia a zongoránál, 1896, 1899 (5. ábra); Misia a zongoránál, Cipa hallgatja, 1897-98 (6. ábra)) nem beállított, mesterkélt portrék, amelyeken egyfajta attribútum vagy a polgári enteriőr elmaradhatatlan kelléke a zongora, hanem pillanatok megragadása, az otthoni légkör és az ottani társaság bensőséges hangulatának rögzítése. Abban nem lenne semmi különös, ha csak önmagában azt a tényt néznék, hogy egy polgári enteriőrben helyet kapott egy zongora, amelyet gyakran megszólaltattak kisebb-nagyobb társasági összejövetelek alkalmával, hisz ez a kor bevett szokása volt. Minden jómódú polgár tartott zongorát a szalonjában, s még ha maga nem is értett a zenéhez, gyermekeit taníttatta zongo-

47 A Musée d'Orsay Misia, Queen of Paris című időszaki kiállításának rövid leírása: http://www.musee-orsay.fr (Utoljára letöltve: 2016. 03. 21. 15:14)

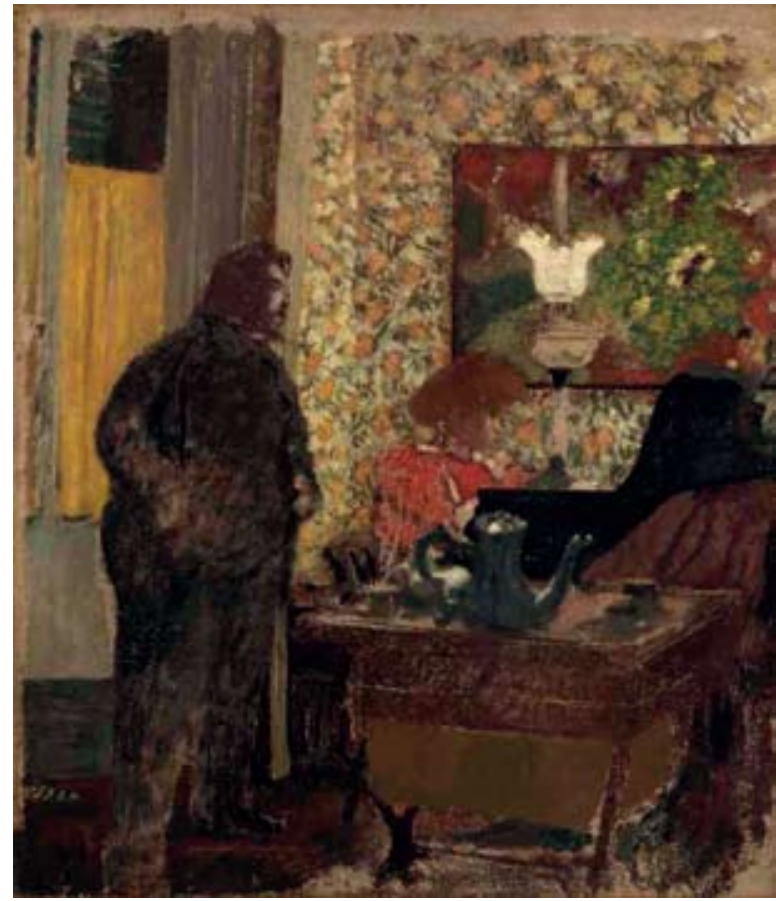

6. ábra. Édouard Vuillard: Misia a zongoránál, Cipa hallgatja (Cipa écoutant Misia au piano), 1897-98. Olaj, karton; 63,5 x $56 \mathrm{~cm}$; Staatliche Kunsthalle, Karlsruhe, Ltsz. 2520 
rázni, amely a műveltség része volt. Itt azonban nem utolsó szempont, hogy Misia nem egy meghívott, ünnepelt művészvendége a szalonnak, akinek hallatára odacsődül a tömeg, mint Munkácsy estélyeire, de nem is egy jómódú polgári család jól nevelt lánya, aki szabadidejében klimpíroz a hangszeren. Mivel hivatalos, nyilvános karrierjét nem építette, a szalonba, zárt ajtók mögé „rejtette” előadóművészi tehetségét, egy szűk és értő kör számára, így egy intim közegben szolgált támpontul a különböző múvészeti ágakban tevékenykedő alkotók egységéhez és kibontakozásához.

Rippl-Rónai jó viszonyban volt Natansonékkal, akik többször látogatták meg őt Neuilly-ben, így valószínű, hogy ez a látogatás kölcsönös volt. ${ }^{48} \mathrm{~A}$ Natanson szalonban egy újfajta hozzáállást tapasztalhatott meg, amely merőben más volt, mint amelyben azelőtt Munkácsy estélyein részesülhetett. Itt a zene a hétköznapi élet szerves része volt, de úgy, hogy az otthon intim légkörében a hallgatónak a zenébe való belemélyedésre, átélésre is nagyobb volt a lehetősége és igénye. A zenére irányuló ilyen fokozott figyelem a wagnerizmus hatásáról tanúskodik. Ebbe a rendkívül elit és szűk körbe csak az kapott meghívást, akit arra érdemesnek és méltónak találtak, mind emberileg, mind művészileg. Rippl-Rónai idegen és ismeretlen festőként ennek a körnek a tagja lehetett, méghozzá úgy, hogy ők figyeltek fel rá, s vonták be társaságukba. ${ }^{49}$ Itt köttetett barátságai egész életében jelentősek maradtak, amint az kitűnik Emlékezéseinek soraiból is. 1910-es párizsi útja során végig látogatta egykori barátait, s a beszámolóból kiderül, hogy természetesen mozog ezekben a körökben. ${ }^{50}$ Vuillard-nál tett látogatása kapcsán újra viszontlátott öreg barátai között említi Hermann muzsikust, ${ }^{51}$ aki véleményem szerint azonos azzal a Pierre Hermant-nal, akit tiszteletbeli Nabiként tartottak számon a „Revue blanche festői”. Habár ma már ismeretlenül hangzik Hermant neve, az 1890-es években ez nem így volt; művei és zenekritikái egyaránt megjelentek a Revue blanche-ban. ${ }^{52}$

Rippl-Rónai franciaországi zenészkapcsolatairól sok esetben csak feltételezéseink lehetnek, mivel Emlékezéseiben is olykor ködösen fogalmaz egy-egy személy kapcsán. ${ }^{53}$ Ezeknek a köröknek a zenéhez való hozzáállása azonban olyan meghatározó élményként íródhatott bele emlékeibe, hogy hazatérése után

48 Ld. Natanson 1994, 255

49 Natanson így emlékezett a magyar festővel történt első találkozásra: „(...) többen elmondhattuk, milyen kellemes meglepetés és öröm ért bennünket, amikor egy élénk tekintetü, sápadt kis öreg parasztasszony, egy nagyanyó portréját fedeztük föl a tárlaton. A képen ismeretlen név állt, melyröl addig egyikünk se hallott. Bonnard, Vuillard, Vallotton, Ker Roussel, s azt hiszem, még Maurice Denis is egyként elismerte az ismeretlent, aki teljességgel az volt, hisz akkor még Maillolról, Rippl-Rónai barátjáról sem tudtunk." Ld. Natanson 1994, 254-255. Rippl-Rónai úgy emlékszik barátaival való megismerkedésére, hogy azt a svájci Jean Schopfernek köszönheti, aki az Öreganyám sikerét követöen Natansonnál „egy minden ízében magyaros vacsorát rendezett” az ő tiszteletére. Ld. Emlékezések 1957, 113.

50 Emlékezések 1957, 101.

51 Uo.

52 Vaughan, G. 1984, 41.

53 Ld. Lerolle esetében: Emlékezések 1957, 103 saját környezetének kialakításában is nagy szerepet játszhatott. Azáltal, hogy itthoni tartózkodása során impulzusai továbbra is a francia fővárosból érkeztek, az ott tapasztalt szokások és hatások a megvalósítás során egy új, jellemzően magyar közegben nyertek új értelmet. Ez nyilvánvalóvá teszi számunkra is, hogy Rippl-Rónai megértette és magába szívta azt a felfogásmódot, amely a francia hagyományban gyökerezik, ám egészen újfajta megoldásokat kínál.

\section{A megvalósítás színtere - Kaposvár}

\section{A beleélés módjai}

Rippl-Rónai hazaköltözése után, első kaposvári korszakában vált igazán fontossá az intim enteriőr, melynek alakjai családtagjai, szerettei, barátai, akiket legtöbbször valamilyen elmélyült foglalatosság közben örökít meg (Piacsek bácsi a fekete kredenc elött, 1906). Ezek az állapotképek egyfajta lélekábrázolást is magukba foglalnak, egy-egy alakban az adott személy egész karakterét képes megragadni, s arckifejezésével képes átadni egész gondolatvilágát. ${ }^{54}$

Rippl enteriőrjeinek modelljei legtöbbször teljesen abszorptív módon jelennek meg. Ennek jó példája a Piacsek bácsi a fekete kredenc elött (1906) (7. ábra), amelyen az öregúr teljesen belemélyed az olvasásba, vagy a Piacsek bácsi babákkal (1905) című kép, amelyen a két kislány sincs tudatában a festés tényének, Piacsek bácsi pedig nyugodtan pipálgat. Mindeközben a háttérben a festő által kedvelt nyitott ajtón át a néző beláthat a másik szobába, ahol a varrónő épp egy ruhát próbál Lazarine-ra. ${ }^{55}$ Ezek az életképek, amelyek a legnagyobb természetességgel kapják el a pillanat hangulatát, visszaidéznek valamit a 17. századi holland zsánerképek enteriőrjeinek foglalatoskodó alakjaiból, ahol általában a nőké volt a főszerep, akik gyerekneveléssel, kézimunkázással, beszélgetéssel, olvasással vagy csak merengéssel töltik az időt. ${ }^{56}$ Tulajdonképpen ez a hagyomány élt tovább Rippl és a Nabik enteriőrképeiben is, ${ }^{57}$ azonban náluk mást akar kifejezni ennek a mikrovilágnak a megmutatása. A 17. században egyfajta morális tanítás is kapcsolódhatott ezekhez a művekhez, gondoljunk csak Vermeer képeire. A Nabik és Rippl ezzel szemben a saját belső világukat tárják elénk saját otthonuk megfestésével, s hangsúlyozzák is, hogy szereplőik kicsodák, hozzátartozóik, számukra fontos személyek, akik által az egész enteriőr személyessé válik. Ennek feltárása sokkal merészebb, megmutat valamit az ő mikrovilágukból,

54 Ld. Emlékezések 1957, 86.

55 A kép tárgyának leírásával kapcsolatban Id. Rippl-Rónai levelét Ödönhöz (Kaposvár, 1905. nov. 30.)

56 A 17. századi holland életképekkel kapcsolatban Id. Alpers, S 2000; Mojzer M. 1967

57 A 17. századi holland enteriőrképek jelentik a kulcsot Vuillard enteriőrjeihez is. Vuillard föleg Johannes Vermeer, Jan Steen és Gerard Dou müveit rajzolta, amelyeket a Louvre-beli rendszeres látogatásai, valamint belga, holland és londoni utazása (1892) során ismert meg. Enteriőrképeinek másik forrása Jean-BaptisteSiméon Chardin művészete, akinek csodálta szerény, egyszerü témáit és „tonális harmóniáinak tiszta és egyszerü gyönyörüségét”. Ld. Vuillard 2003, 130. 


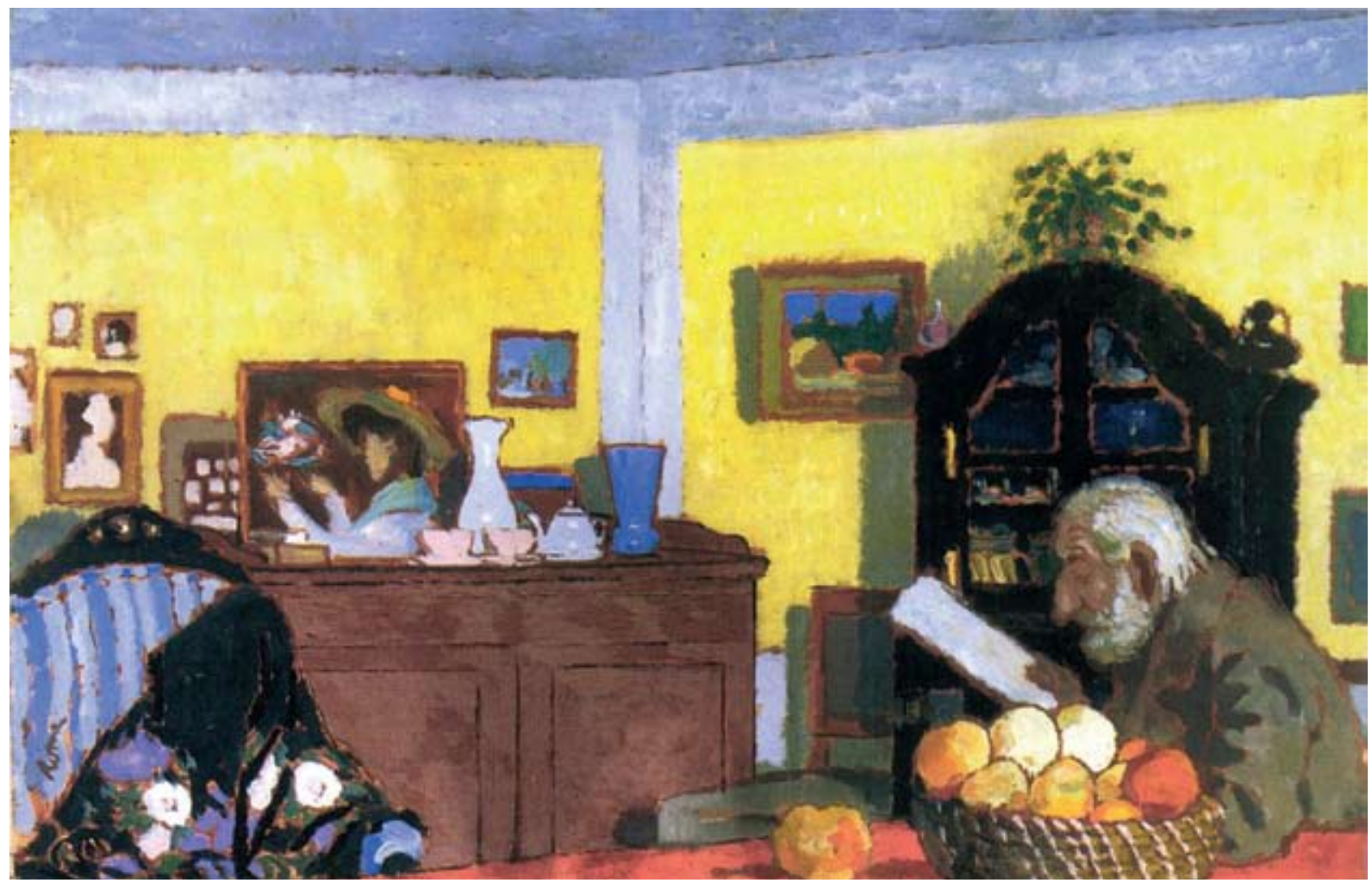

7. ábra. Rippl-Rónai József: Piacsek bácsi a fekete kredenc előtt, 1906. Olaj, lemezpapír; 67x97,5 cm; Magántulajdon

személyes tárgyaikból s hétköznapi elfoglaltságukból, melyekkel a kor polgárai könnyen megbarátkoztak, magukra ismertek.

Rippl abszorptív ábrázolási módja abba az antiteátrális hagyományba illeszkedik, amelyről Michael Fried értekezik, ${ }^{58} \mathrm{~s}$ amely a Nabik enteriörképeire is jellemző. Ez lehet kulcs a zeneszobák és egyéb zenei tárgyú, zenehallgatást megjelenítő müvekhez is. Az ilyen típusú képek önmagukban léteznek, a kép szereplői függetlenek a kép nézőjétől. Ennek az antiteátrális hagyománynak egyik legkorábbi mestere a francia Chardin, akinek müvei nem kívánják meg a néző jelenlétét, szereplői teljesen elmélyülnek cselekvésükben. ${ }^{59}$ Rippl művein is ilyen helyzetnek vagyunk tanúi, szereplői is csaknem kizárják a nézőt a jelenetböl. Rippl azonban mégis nyit a befogadó felé, s bár ezek a jelenetek nélkülünk zajlanak le, mégis lehetőségünk nyílik arra, hogy ott legyünk abban az enteriőrben és részesüljünk abból a hangulatból, amelyben a szereplők élnek. Amikor Rippl rokonai elmélyült cselekvését ábrázolja, megengedi a nézőnek, hogy lássa a cselekvés hatását képe szereplőjén. Így olyan pillanatnyi állapotokat rögzít, hogy milyen hatást vált ki Piacsek bácsiból az olvasott könyv vagy újság, milyen érzések, hangulatok ragadják el az emlékezéseiből élő anyát, a szomorkodó vagy merengő Lazarine-t.

58 Ld. Fried, M. 1980

59 Jean-Baptiste Siméon Chardin: Buborékot fújó fiú (1733-34 körül); Kártyavár (1737 körül); $A$ fiatal tanítónő (1740 után). Mindhárom a washingtoni National Gallery of Art tulajdona.
Rippl zenei témájú művei között található egy igencsak érdekes enteriőrkép ebböl a korszakból, amely nem kis figyelmet érdemel, ha a francia hagyomány szempontjából is megvizsgáljuk. Az Öregúr és mandolinozó asszony (1905) (8. ábra) címü kép némiképp eltér azoktól a képektől, amelyeken az enteriőr szereplői abszorptív módon jelennek meg. Míg Lazarine elmélyül a mandolinozásban, az öregúr sanda mosolylyal tekint ki a képből. Piacsek bácsi teljesen tudatában van annak, hogy ez a jelenet meg lesz örökítve, kitekint a festőre s ezáltal kapcsolatot teremt a nézővel is. Ugyanakkor ez az arckifejezés egyben elmélázó is, melynek oka Lazarine mandolinjátéka lehet. Ez Rippl első képe, melyen a zenejátszás mellett megjelenik egy zenét hallgató személy is, akin láthatjuk a zene által kiváltott érzéseket. A hátrafelé megnyíló újabb terek utalhatnak a szereplők belső világára, amely vibráló halványkékjével a lélek mélységeit tárhatja fel, melyben a zenének fontos szerepe lehet. A modern francia festők gyakran kísérleteztek egy képen belül az antiteátrális hagyomány megtartásával és megtörésével egyaránt, így ez a fajta hozzáállás Rippl esetében ismét e körök hatásáról árulkodik. ${ }^{60}$

\section{Élet a Róma-villában}

Ami Rippl-Rónai életmódját illeti, 1908-ban a Rómavilla megvásárlásával kezdődhetett meg a beteljesülés időszaka, 1906-os sikerét követően itt mindent a maga

60 Ld. Fried elemzéseit a témában: Fried, M. 1998, 185-261. 


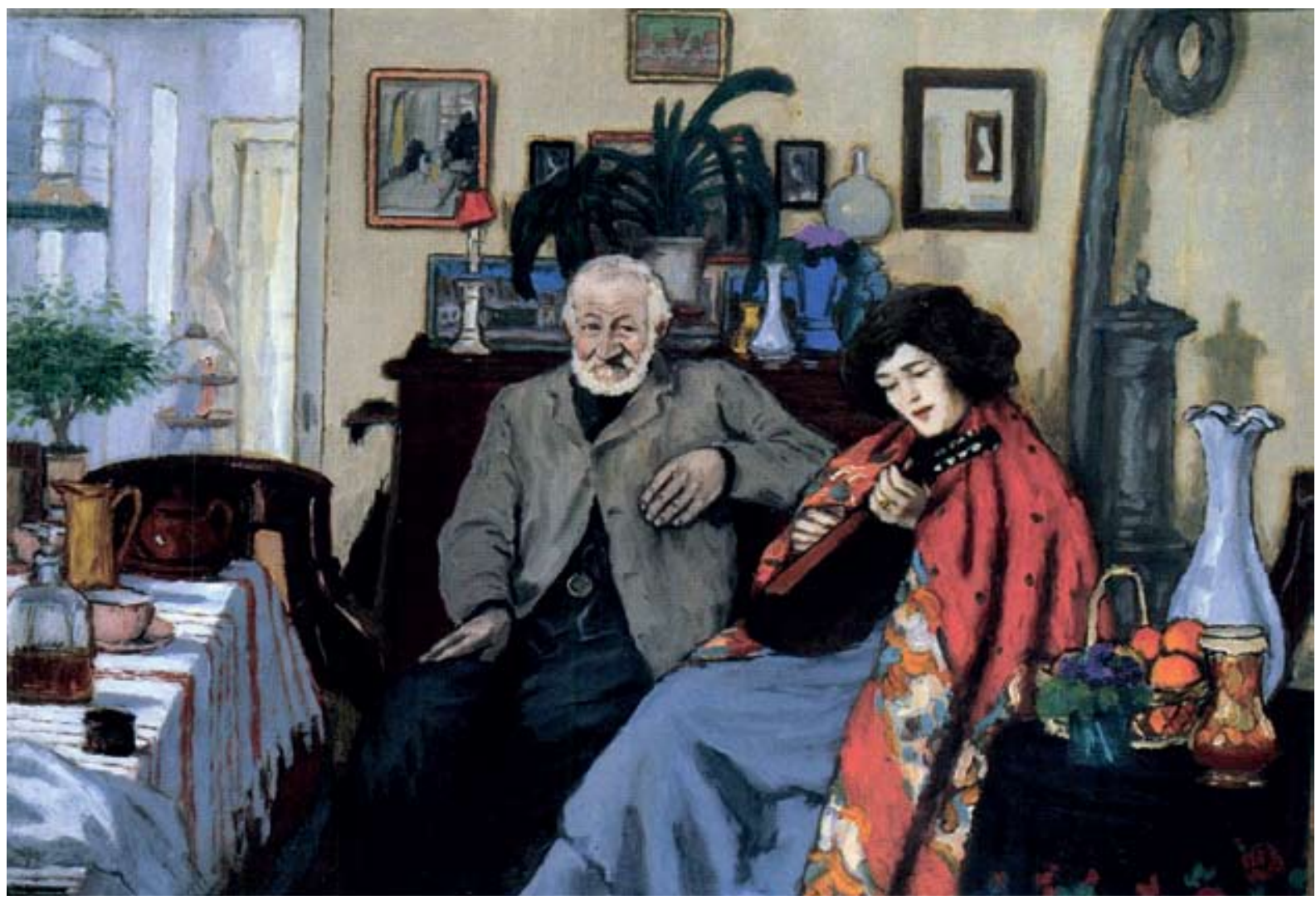

8. ábra. Rippl-Rónai József: Öregúr és mandolinozó asszony, 1905.

Olaj, lemezpapir; 73×102 cm; Magántulajdon

ízlése szerint alakíthatott ki. Minthogy Paris Anella 1910től családtagként élt a villában, visszaemlékezései értékes információkat nyújtanak a villa-beli életről. Innen van tudomásunk arról, hogyan zajlottak a mindennapok a Róma-villában. Abban a napi ritmusban, amit Rippl-Rónai itt kialakított, nagy szerepe van franciaországi éveinek: a reggeli koránkelés, az azt követő hosszabb erdei séta, amelynek végén a terített asztal várt - kakaóval és vajas kaláccsal - mind a Mailloléknál eltöltött a Banyuls-i időszak élményeiből táplálkozik, ahol ez a napi rítus volt szokásban. ${ }^{61} \mathrm{Az}$ ottani falusi természetközeli lét itt Kaposváron új formát öltött, amelyhez a Párizsból hozott társasági életre való igény társult, s ebben a légkörben Rippl-Rónai ezúttal igazán otthon érezhette magát.

A megváltozott életkörülmények harsogó színskálát és a képtémák megváltozását hozták magukkal. ${ }^{62} \mathrm{~A}$ Fő utcai ház enteriőrképeinek csendes, elmélázó nyugalma a Róma-villában élénkebb társasági jelenetekké alakult, illetve egyre több olyan képet találunk, amelyek a Róma-villa zenei életéről tanúskodnak. A sárga szín iránti vonzalma szintén már Banyuls-ben megmutatkozott, ahol a fekete korszak melankóliája után felfedezte a színek erejét és szépségét. ${ }^{63}$ Ezúttal saját villájának

61 Ld. Horváth J. 1995, 51.; Emlékezések 1957, 52.

62 Ld. erröl Rippl-Rónai önvallomását: Emlékezések 1957, 63-64.

63 „Rendkivül tipikus szín itt a sárga. Ilyen a falak színe, és a fedelek színe is sárgásvörös. A konyhák különösen nagyon sárgák, vörös téglákkal..." Ld. Rippl-Rónai levele Ödönnek, Banyuls sur Mer, 1899. szept. 10. (Közli: Bernáth M. 1998, 115.) több falát az említett krómsárgára festette, melynek forrósága izzó életvidámságot fejez ki. Rippl életében ez a fordulat egybevágott azzal a művészeti megújulással, amelyet a vadak hoztak intenzív tiszta színeikkel.

\section{Rippl-Rónai zongoraszobája}

A Róma-villa földszintjén az ebédlő vagy társalgó felől mindkét irányba egy-egy szoba nyílt, jobbra a dolgozószoba, balra pedig a zongoraszoba. ${ }^{64} \mathrm{~A}$ sárga szín uralta a zongoraszoba falait is, ahol egyre gyakrabban igencsak élénk társasági élet zajlott. Ugyanakkor azok a festményei, amelyek ebben az enteriőrben készültek intim családi jeleneteket ábrázolnak, hasonlóan Vuillard és Bonnard enteriőrképeihez. Ezeket a képeket eddig ritkán vizsgálta a szakirodalom, pedig nem kis figyelmet érdemelnek - különösen a Róma-villa-beli életmód fényében. Az 1910 körüli években egyszerre több zenei témájú műve is készült, ami pedig a Róma-villában kialakított új életmóddal lehet összefüggésben.

Martyn Ferenc, aki testvérével együtt a Rómavillában nőtt fel, szintén részese volt ennek a színes életnek. ${ }^{65}$ Emlékezéseiben említi is, hogy a zene mennyire elválaszthatatlan volt a Róma-villa lakóitól.

64 Horváth J. 1998, 169.

65 A Martyn gyerekek édesapja, Martyn Arthur Piatsek Margit testvérét, Gizellát vette feleségül. Gizella a hatodik gyermekük szülése során halt meg, ezért Rippl-Rónaiék az öt gyermek (Ferenc, Mária, Róbert, Arthur és Andor) közül a két idősebb fiút nevelt fiúkká fogadták. Vö. Horváth J. 2007, 18. 


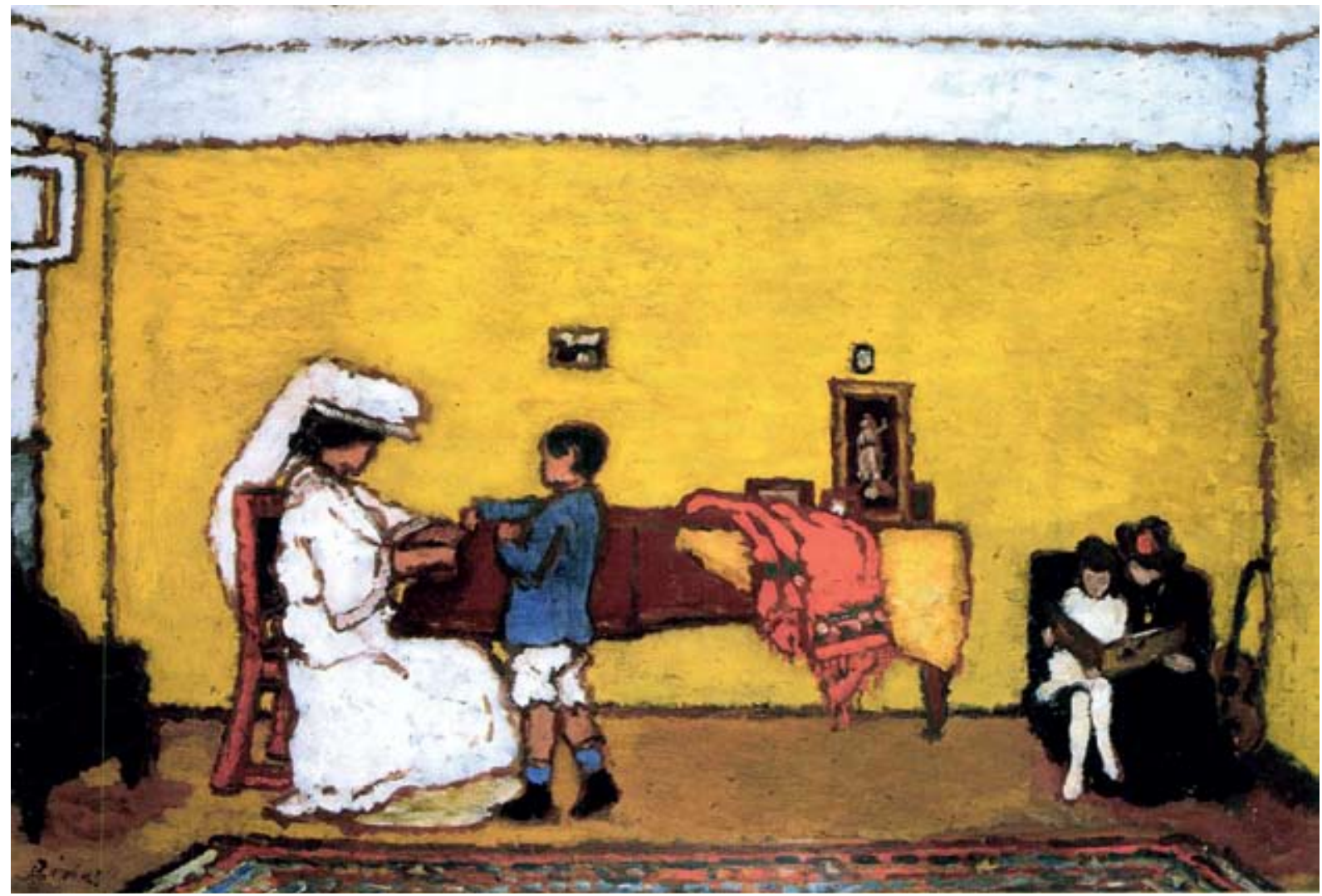

9. ábra. Rippl-Rónai József: Sárga zongoraszoba, 1910.

Olaj, lemezpapir; $68 \times 100$ cm; Magántulajdon

„A festő néhanapján kinyitotta az Ehrbar-t és lapról játszott. Lajos öccse hegedült (...). Sándor pedig az Operaháznak volt tagja, igazi századeleji bohém, vele érkezett - néhanapján - felesége, Dóra asszony maga is énekes, olasz opera-ária müsort adtak elő családiasan, mindnyájunk csodálatára. Mert Rippl-Rónai házában áhitatos csendben, mozdulatlanul hallgattuk a muzsikát."'66 A Sárga zongoraszoba (1910) (9. ábra) jól reprezentálja azt a „szentélyt”, ahol a zenei élet zajlott. Majdnem a kép egész terét kitölti a sárga fal előtt álló zongora. Martyn Ferenctöl tudjuk, hogy a fehér kalapos zongorázó hölgy Lazarine, míg a hallgató kisfiú ő maga. ${ }^{67}$ A Sárga zongoraszoba párhuzamba hozható Vuillard Misia a zongoránál (1899) (5. ábra) című képével. Amint Vuillard, Rippl is a szobának csak azt az egy falát emeli ki, amelynél a zongora van, de nem hagyja le az ott lévő hallgatókat a képről.

Korábbi enteriőrképeihez képest itt a sárga fal zárja le a képteret, nincs helye hátrafelé megnyíló új tereknek. Ilyenformán ez a Piacsek bácsi a fekete kredenc előtt (7. ábra) című képen alkalmazott térkezelési mód még letisztultabb formája, annak továbbredukálása egy egyszerü, egyszínű sík fallá. Az ott megmutatkozó abszorpció itt is jelen van, ám ezúttal a szereplők több érzékszervét veszik igénybe a különböző cselekvések. Míg Vuillard képén a hallgató szinte csakis kizárólag a merengéssel, a zene hallgatásával van elfoglalva, addig Rippl-nél párhuzamos cselekvéseket látunk. A zenejátszás, zenehallgatás mellett az olvasás is megjelenik, amely ugyancsak a külvilág kizárását váltja ki a szereplőkből. A látás és a hallás párhuzamos megjelenítése kap hangsúlyos szerepet ebben a szobában, amint Rippl maga is az előbbi érzékszerv segítségével figyeli meg képének tárgyát, miközben a szobát betöltő zenét hallgatja. Az oldott ecsetkezelési mód is Vuillard festésmódját idézi, habár Rippl-Rónainál nagyobb szerepe van a vonalnak. Vuillard dekorativitása és foltkavalkádja mégis érzékeltet némi térmélységet, Rippl pedig egy doboztérbe helyezi az egyszerü és letisztult színekkel megfestett jelenetet. Mindkét esetben a harmonikus egység, amely a képet uralja, s az ecsetkezelés ritmikus volta utalhat a zenei tartalomra is. Nagy a hasonlóság a figurák megformálásában, különösen abban az elnagyoltságban, amellyel az arcok vannak megfestve. A vonások elhanyagolása arra mutat, hogy a személy karakterének megragadása és a mozdulat frissessége fontosabb, mint az arc aprólékos kidolgozása. Ettől az alakok a dekoratív, vagy éppen egyszerüen letisztult tér szerves részeivé válnak, mely kifejezi Rippl egyszerre festés elvét. ${ }^{68} \mathrm{~A}$ szereplők ezáltal beleolvadnak abba a térbe, amelyet megtölt a zene, s ez a Nabik felfogásmódjával rokonítható. 


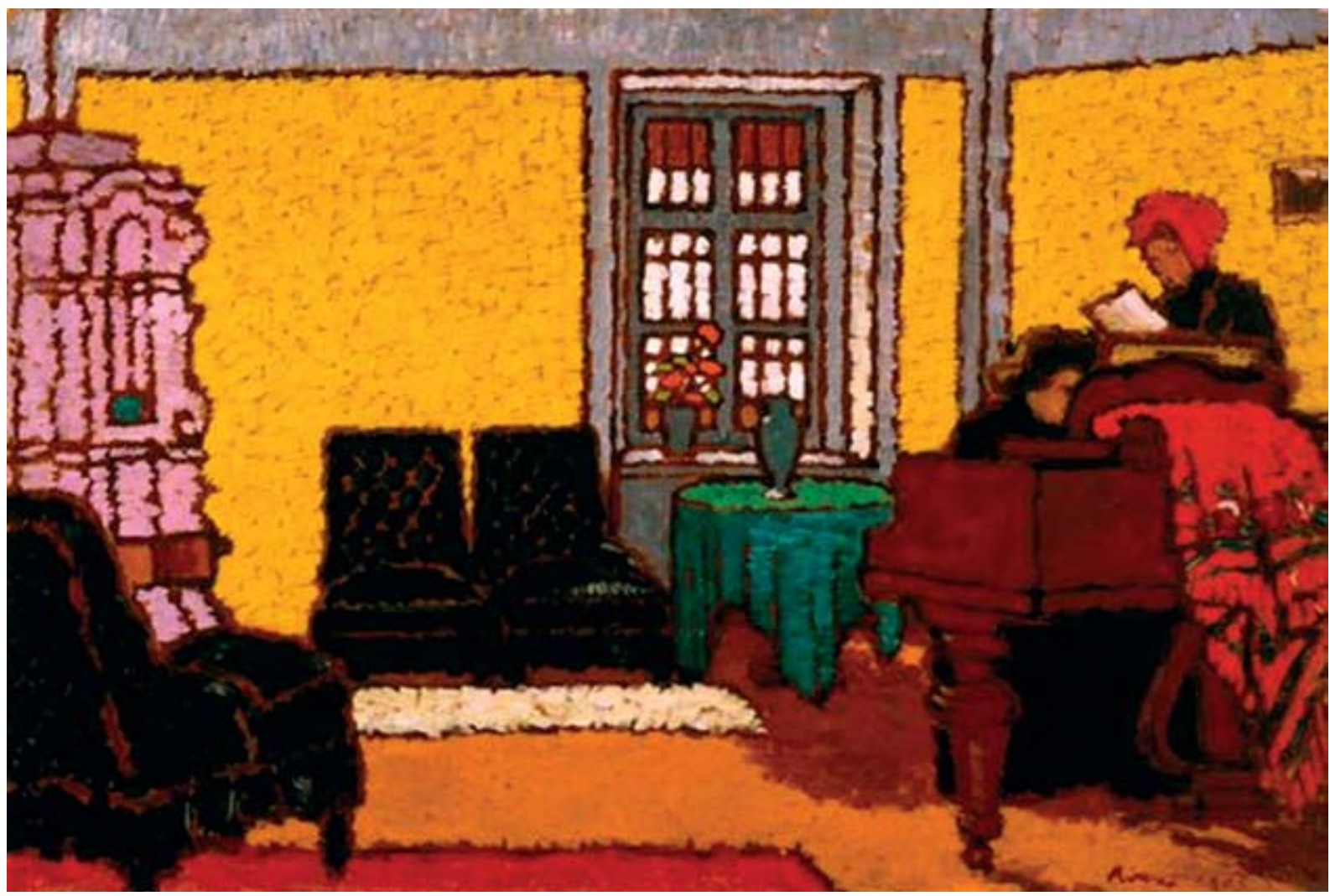

10. ábra. Rippl-Rónai József: Sárga zongoraszoba II., 1909. Olaj, karton; 71 x 103.5 cm; Museum of Fine Arts, Houston, Audrey Jones Beck Collection, Ltsz. 2003.306

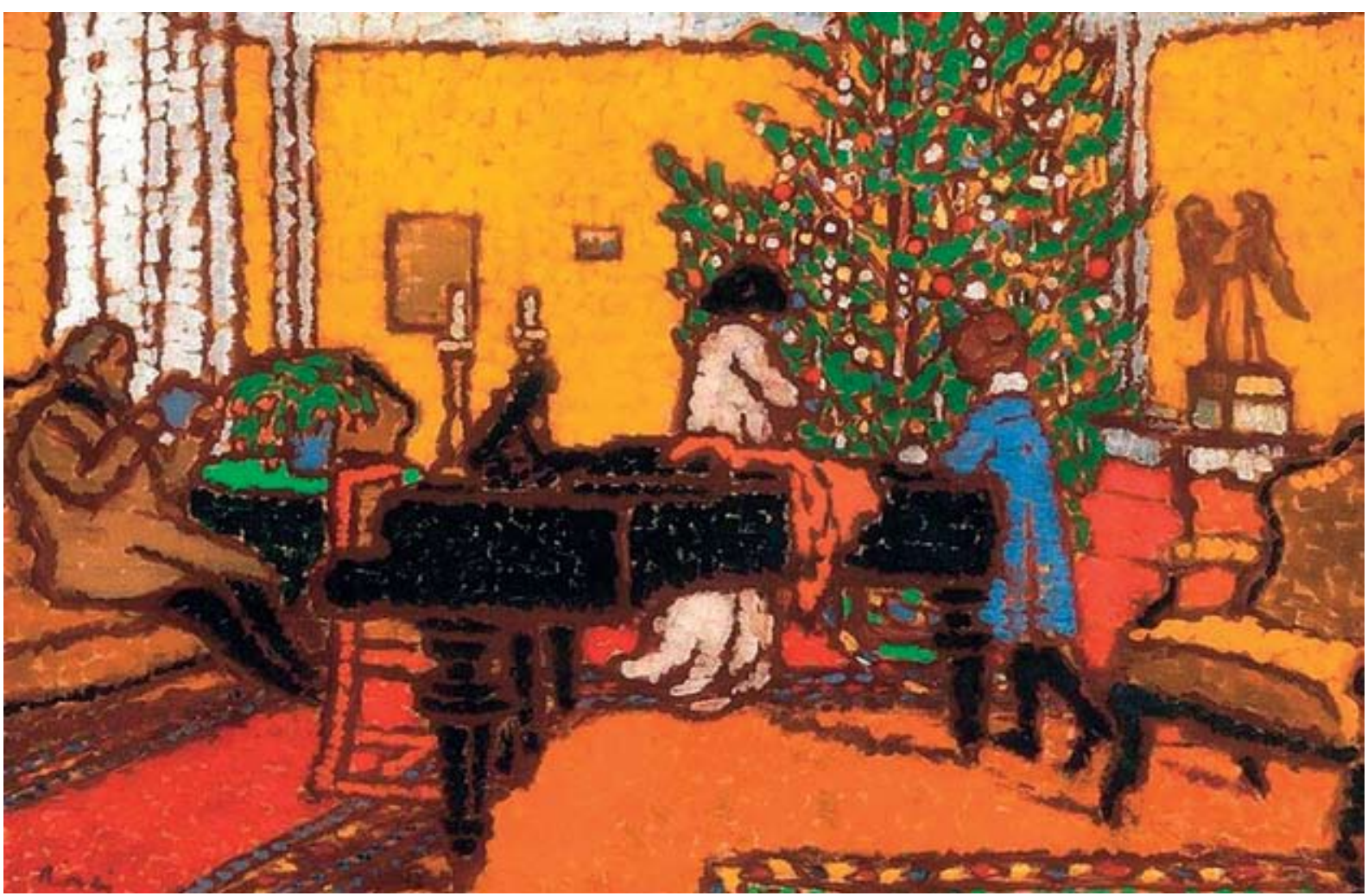

11. ábra. Rippl-Rónai József: Szoba karácsonyfával, 1910 körül.

Olaj, karton; 71 x 103 cm; Magántulajdon 
A kép két jobboldali szereplőjéről Martyn Ferenc nem ad leírást, a kislány nagy valószínüséggel azonban Ferenc húga, Mária lehet, aki Anella visszaemlékezései szerint akkoriban a szünidőt ott töltötte a Róma-villában. ${ }^{69} \mathrm{~A}$ vele egy fotelben ülö fekete ruhás hölgy kiléte azonban kérdéses, Anella ugyanis fiatalabb volt, mint az ábrázolt személy, így ő nem lehet. Mivel a festmény nem egy társasági jelenetet ábrázol, hanem a család intimebb hétköznapját, azok közül a személyek közül való lehet az ábrázolt hölgy, akik tartósan a Róma-villában laktak. 1910-től egy új vendég jelent meg a villában, aki azután majdnem egy éven keresztül ott élt a Rippl-Rónai családdal. Ez a hölgy pedig Fenella, aki egy intenzívebb zenei életet is hozott magával a villába. Anella ad szintén jellemzést Fenelláról, aki egy igen „exotikus” személyként mindig a figyelem központjában állt. Az ő személyére később fogok visszatérni, most csak anynyit említenék, amennyi az azonosításhoz szükséges. Habár a képen nem olyan feltűnő a kinézete, mint amilyennek Anella leírta, mégis valamelyest ráillik a leírás, különösen a nyakában megcsillanó aranyos fényű ékszer. „A hajában, nyakában rézérmékből összeállított láncokat viselt és ugyanolyan fülbevalókat." ${ }^{\prime \prime} \mathrm{Ha} \mathrm{Rippl}$ őt ábrázolta, igencsak visszafogott módon jelenítette meg a viseletét, csakúgy, mint az ékszereket. Ugyanakkor mellette a sarokban egy gitár van a falhoz támasztva, amely kifejezetten az ő attribútuma volt, s amelytől ritkán szabadult meg az őt ábrázoló képeken, így lehetséges, hogy őt látjuk itt is. Kissé furcsa azonban az a csendes, visszahúzódó megjelenése, amellyel a kislány mellett ül, ugyanis minden leírásból arra következtethetünk, hogy az ő extravagáns személyisége mindig a középpontban kívánt lenni, $s$ a zenében mindig aktívan részt vett. Ha mégsem ő szerepel a képen, a gitár jelezheti azt, hogy ő - ha nincs is épp jelen - a zeneszoba aktív tagja. Gitárja a zongorázó Lazarine mellett egy gondosan odahelyezett jel és utalás lehet a villabeli zenei élet sokszínüségére, s magának Fenellának a személyére, aki akkor is nyomot hagy másokban, ha épp testben nincs is jelen.

A Sárga zongoraszoba párdarabja Sárga zongoraszoba II. címen tủnt fel az újabb szakirodalomban, holott egy évvel korábbra datálódik (10. ábra). Ennek oka az, hogy ezt a képet a korábbi kutatás nem ismerte, $s$ Genthon cédulái közt sem találtam semmilyen erre vonatkozó utalást. ${ }^{71} \mathrm{Ez}$ a festmény a zongoraszobát egy másik szögből mutatja, rálátással a zongora egy részére. Minthogy ez a kép 1909-ben készült, sem Anella, sem Fenella nem tartózkodtak még a Róma-villában, így a hangszernél ülő és éneklő hölgyek kiléte felöl nincs semmilyen biztos adatunk. Nagy valószínüséggel a villa vendégei voltak, mivel bárki leülhetett a zongorához, sőt aki tudott muzsikálni, az biztosan számíthatott a mester vendégszeretetére. „A zongora ott mindig jól hangolt állapotban várta a muzsikosokat, akik gyakran

69 Ld. Horváth J. 1995, 50-51.

70 Horváth J. 1995, 54.

71 A kép provenienciájához kapcsolódó kutatási adatokat és feltételezéseimet nem áll módomban itt közölni, mivel azok túllépnék tanulmány kereteit. A kép 2003-as aukciós megjelenésével kapcsolatban Id. Molnos P. 2007, 32-33. voltak vendégei a villának."72 A festő Anella nevelésében is mind az irodalmi müveltséget, mind a zenei oktatást fontosnak tartotta, amint az polgári családban szokás is volt. Ez az igénye azonban kifinomultabb volt, mint átlagos polgári családoké, maga is művész lévén olyan emberek barátságát élvezte, akik mind a művészeti, irodalmi, mind a zenei élet jeles képviselői voltak. A zongora azonban nem Anella nevelésének kapcsán kerülhetett a villába, hiszen már jóval a lány érkezése előtt megvolt, s ez alátámasztja azt, hogy maga Rippl-Rónai igényelte a hangszer jelenlétét. „Kereste és igényelte azok társaságát, akik körülötte zenét szolgáltattak és sajátos világának meghitt hangulatát gazdagították." ${ }^{73} A z$ is lehetséges, hogy ezúttal is Lazarine ül a hangszernél, aki annak ellenére, hogy egy rendkívül egyszerü falusi lány volt, valóban tudott zongorázni. Martyn Ferenc közlése szerint a Fő utcai házban és a Róma-villában is gyakran csendültek fel Lazarine burgundiai dalai, melyekhez később Anella is társult. ${ }^{74} \mathrm{Az}$ ének más formában is jelen volt a villában: néhanapján a festö legfiatalabb öccse, Sándor érkezett látogatóba késő este, ilyenkor korareggel operaáriákkal lepte meg a szakácsnőket. „Felesége, Dóra wagneri szerepekre termett asszony volt, aki itthon olasz áriákat énekelt, de Budapesten csak az opera kórusában kapott helyet."75

Érdekesek a valóságtól eltérő motívumok - föként színkombinációk -, amelyek minden bizonnyal a tudatos festői tervezés eredményei. Az Ehrbar zongora Martyn emlékezései szerint fekete, Rippl-Rónai egy másik képén - amely ugyanebben a szobában készült - valóban fekete színű, ezen a képen és párdarabján azonban barna. Rippl a kompozíció kiegyensúlyozottsága érdekében tehetett ilyen módosításokat, hiszen a képen feketék a bútorok, valamint a két hölgy is feketébe öltözött. Ezt némiképp ellensúlyozza a hangszer barna színe, ami ezáltal el is válik a hölgyek fekete ruhájától, s térben is kissé kiemelkedik a kép síkszerüségéből. Ez jól mutatja, hogy Rippl enteriőrjei nem merülnek ki a látvány hiteles másolásában, a festő szabadon kezeli a színeket, melyek a kompozíció tökéletessége érdekében olykor a valóságtól eltérnek. Míg a „cselekmény” a jobb peremre szorult, a középtérben két hatalmas üres fekete fotel vonja oda a tekintetet, mintha Rippl ezzel helyet kínálna a kép nézőjének, hogy hallgatóvá váljon. Ezt erősíti a zongorával átellenben elhelyezett harmadik, ugyancsak fekete fotel, amely szintén üres s kompozíciós elrendezésével bevonja a nézőt a kép terébe.

A Róma-villában karácsonykor a karácsonyfát is a zongoraszobában állították fel. ${ }^{76}$ Erről tanúskodik a Szoba karácsonyfával (1910 körül) (11. ábra), amelyen ugyanazt a teret látjuk, mint a Sárga zongoraszobán. A sárga fal a sarkoknál megtörik, csakúgy, mint a Sárga zongoraszoba II-n. Ezzel egyszerre fokozza a dekora-

\footnotetext{
72 Pandur J. 1985, 58.

73 Pandur J. 1985, 57.

74 Martyn F. 1979, 122; Pandur J. 1985, 58

75 Pandur J. 1985, 59. Rippl-Rónai budapesti tartózkodásai alkalmával gyakran látogatta az Operát, ahol öccsét is láthatta, min az leveleiböl is kiderül. Ld. Ödönhöz írott levele (Budapest, 1903. jan. 3.) MTA MKCS-C-I-36/474

76 Horváth J. 1998, 169.
} 


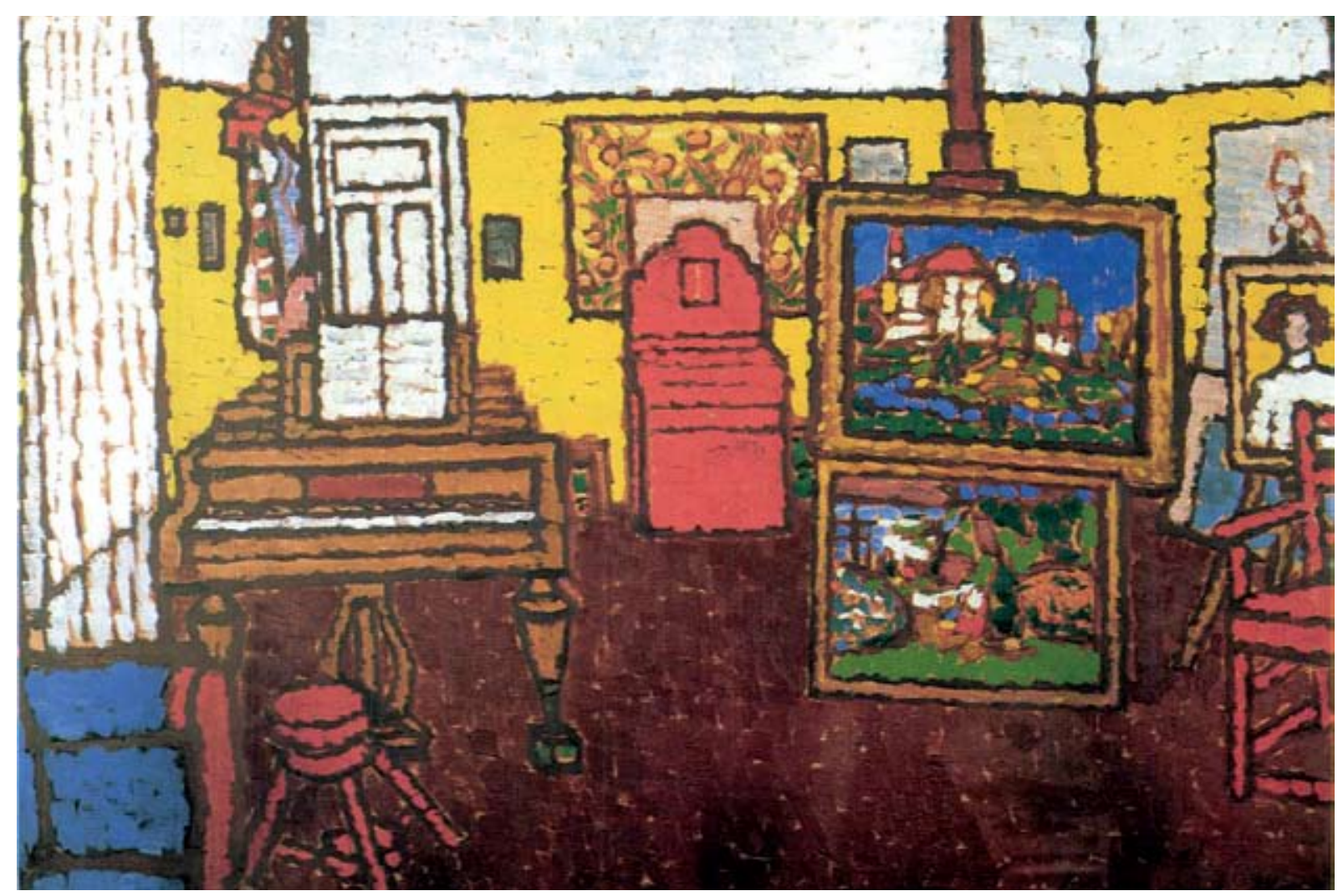

12. ábra. Rippl-Rónai József: Müterem intérieur, 1910-es évek.

Olaj, lemezpapír; 68,5 x 101 cm; Magántulajdon

tivitást és a térhatást is, egyfajta ritmust ad a képnek, ellenben a Sárga zongoraszobán egy nagy egységes - osztatlanul sárga - falfelület előtt jelenik meg a hangszer, mellyel a néző tekintetét jobban arra irányítja. Rippl-Rónai karácsonyi témájú müvei közt ez a legvidámabb hangulatú kép, melyen a nagy fekete zongora mögött Lazarine és Anella díszítik a fát, míg bal oldalt a pamlagon egy úr olvas. Rippl-Rónai apja és Piacsek bácsi is még a Róma-villába költözés előtt (1908-ban) elhunyt, így ők nem lehettek e kép modelljei. Annál inkább lehet viszont a „Kossuth-imádó Rippli bácsi”, ${ }^{77}$ aki az Ivánfa hegyen lévő szőlőjéből télire leköltözött a villába. Ezt épp az 1910-es tél és karácsony kapcsán említi Anella - tehát a kép készülésének idején -, amikor Fenella is a villában lakott. ${ }^{78}$

A kiegyensúlyozott kompozíciójú kép középterét uralja a zongora, amely feketeségével kiemelkedik a kép teréből. Felfogásában hasonló Vuillard A szalon három lámpával, rue Saint Florentin (1899) című képéhez, amelyen a csendesen sziesztázó alakokkal egy térben a kép szélén árválkodik üresen a zongora. Rippl mozgalmas kompozícióján, habár középre került a hangszer, mégis ugyancsak némán áll ott, s a családtagok más tevékenységgel vannak elfoglalva, hasonlóan, mint Vuillard festményén. Rippl-Rónai az intenzív színfoltokkal kiemel egyes részleteket, így Lazarine fehér és

77 Rippl János (1832-1915) a festő apjának testvére volt. A RipplRónai családfát Id. Horváth J. 2007, 16.

78 Horváth J. 1995, 55
Anella kék ruhája erősen elüt a komplementer színpár vörös-zöld uralta környezettöl. Lazarine ruhája a fényárban úszó ablakkal van összhangban, míg Anella kékje a karácsonyi kaktusz cserepével, valamint Rippli bácsi könyvének azonos színével. Két irányt határoz meg Rippl a képen, az egyik a vörösekkel kijelölt vonal (a szekrénytől a kendőn át, a széken keresztül a szőnyegig), a másik pedig a feketék (Rippli bácsi lábától és a szekrénytől a zongorán keresztül Anella és a karosszék lábáig). Ez a két út, melyeket a színekkel jelöl ki, középen a zongorában találkoznak, amely a leterített vörös kendővel jelenti a metszéspontot. Ez a kiemelés eltereli a figyelmet a háttérbe szorult cselekményről, s az elhalkult zongorára irányítja. Ezt a tényt erősíti meg a jobb oldalt üresen álló karosszék, mellyel ez a mü a Sárga zongoraszobás képek ellenpontjául határozható meg.

Rippl-Rónai nemcsak a zongoraszobát festette krómsárgára. „A polgári lakások historizáló pompájával szemben a Párizst megjárt festő tudatos formabontása volt a falsíkok élénk színezése." ${ }^{79}$ Amint emlékezéseiben írja: „az egyik oldalán csupa-ablak mühelyem falai is ezzel vannak befestve, sőt még ilyen szobában alszom is". ${ }^{80}$ Erről a müteremröl, amelyet a festő a villához tartozó vincellérházból alakított ki, szintén több enteriörkép készült. Ezek közül a Müterem intérieur (1910-es évek) (12. ábra) címü festményt

79 Rippl 1998, 333. (Gergely Mariann képelemzése)

80 Emlékezések 1957,64. 
érdemes megvizsgálni, amelyen ugyancsak szerepel egy zongora. A szakirodalom gyakran említi, hogy a zongora, a kasmírkendő és a piros támlás szék rendszeres motívumok Rippl-Rónai képein, itt azonban érdemes megállni egy pillanatra. Habár a müterem falai épp ugyanolyan sárgák, mint a zongoraszoba falai, ez a kép azonban nem a zongoraszobában készült, ahol természetes, hogy zongora van. Ez a festő mühelye, amelyröl Horváth János azt írja, hogy később ide került át a bécsi hangszer a villából. ${ }^{81} \mathrm{Nem}$ tudjuk, mit jelent ez a „később”, hiszen Balogh Rudolf 1912es fényképén már ott van a zongora a müteremben (13. ábra). ${ }^{82}$ Mindenesetre kérdés, miért tart egy festő zongorát a mütermében. Míg a zongoraszoba sokkal inkább a társasági élet színtere, egyfajta szalon, addig ez a kis müterem a festő intim tere, ahova visszavonulhat akkor is, ha a társaság már túl harsány a zavartalan munkához. Bár a források szerint ritkábban dolgozott ebben a müteremben, hiszen elsősorban a kertben festett, de tudomásunk van arról is, hogy munka közben időnként pihenésképp egy negyedórára leült a zongorához, játszott kicsit, majd újult erővel folytatta a festést. ${ }^{83}$ A nyitott zongora, rajta a nyitott kottával jelzi azt, hogy a hangszer folyamatos használatban van. Mivel azonban a szoba üres, sokkal valószínűbb, hogy a festő a dolgos hétköznapokat kívánja bemutatni, melynek része volt az is, hogy festés közben ő maga ült időnként a zongorához. Ezzel a képpel betekintést enged a saját intimszférájába, művészi alkotóéletébe, amelyben a zene is helyet kap.

\section{Rippl-Rónai grafikái}

Rippl-Rónai 1910-ben írta Emlékezéseit, melynek illusztrációi között számos zenei témájú grafikát talál az olvasó. Ez jól mutatja azt, hogy éppen abban az időben mennyire intenzív volt a festő művészetében a zene iránti érdeklődés. Szándékosan válogathatta bele éppen azokat a rajzokat, melyekkel ezt az érdeklödését fejezi ki. Az, hogy ennyi zenei tárgyú rajza született akkoriban, az annak köszönhetö, hogy a mester szervezésének köszönhetően az 1910-11-es évben különösen gazdag volt a zenei élet a Róma-villában.

\section{A Fenella-sorozat}

„A kaposvári villának szerintem egy feltünő tulajdonsága volt; a vendégjárás gyakran bátran eltúlzottnak volt mondható" - emlékezik vissza Anella. ${ }^{84}$ A vendéglista, mely az évek során egyre nőtt, csupa olyan emberből állt, akik az akkori művészeti élet meghatározó alakjai voltak. Művészek, művészettörténészek, írók, költők és zenészek egyaránt gyakori vendégei voltak a villának. A Róma-villa egyik legkülönlegesebb vendége azonban ismét csak Párizsból érkezett. Rippl-Rónaiék 1910-es párizsi tartózkodásuk alkalmá-

81 Horváth J. 1998, 169

82 Rippl-Rónai József müterme, 1912, Balogh Rudolf felvétele. Megjelent: Petrovics E. 1912, 777-783.

83 Vö. Horváth J. 1998, 169.

84 Uo., 53

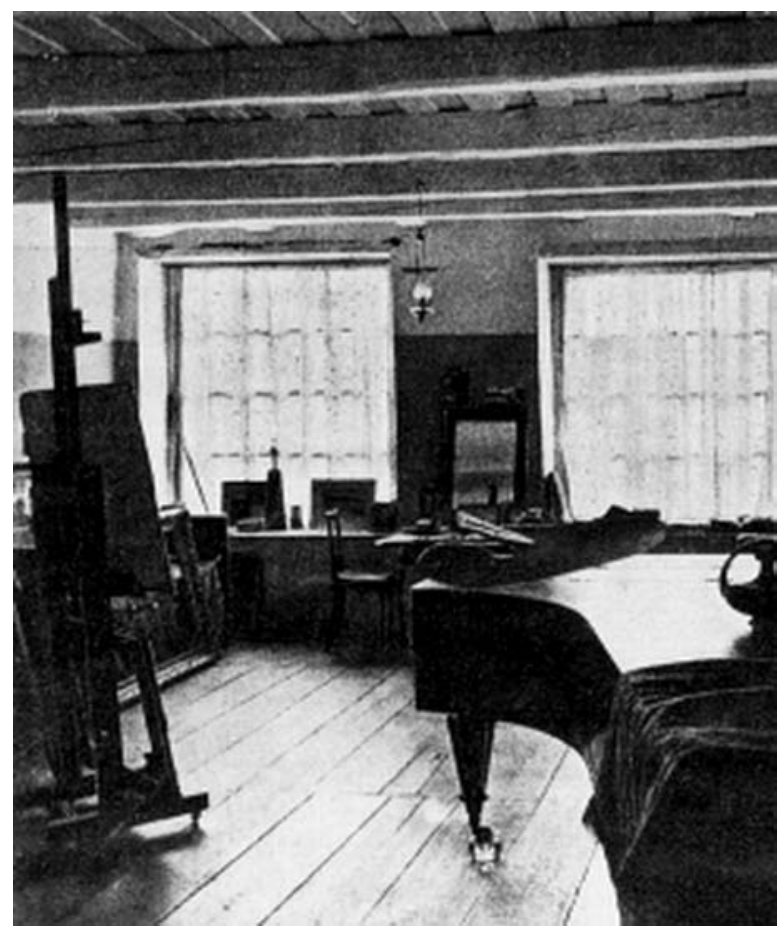

13. ábra. Rippl-Rónai József müterme, 1912. Balogh Rudolf felvétele

val ismerkedtek meg a Párizsban élő félig amerikai cigánylánnyal, Fenella Lowell-el. ${ }^{85}$

Amikor 1910-ben Rippl-Rónaiék Anelláért mentek Lazarine szülőfalujába, természetesen megálltak Párizsban. Itt Galimberti Sándor szobát bérelt a párnak a Hotel de la Haute-Loire szállodában, mely a Boulevard Montparnasse és a Boulevard Raspail sarkán állt. ${ }^{86}$ Egy délelőtt az egyik terem előtt elhaladva ismertek rá a Csak egy kislány van a világon címü magyar nótára, melyet valaki rossz kiejtéssel, gitárkíséret mellett énekelt. Rippl-Rónai benyitott a szobába, hogy megtudja, ki énekli Párizsban egyik kedvenc nótáját. A szőnyegen egy különös ruházatú, furcsa megjelenésű fiatal nőt láttak, aki tudomást sem vett róluk, annyira bele volt merülve énekébe, amelyet - mint később kiderült - magyar festőktől tanult, akiknek modellt ült. Kiderült, hogy zenei müveltsége igen nagy, francia, angol, olasz, spanyol, német, orosz és cigánydalokat is tud, a nyelveket beszéli is, ezenkívül remekül zongorázik. Az ismeretség eredményeként Fenella még abban az évben leköltözött a Róma-villába, ahol kilenc hónapon át szinte családtagként élt velük. Megjelenése rendkívül egzotikus volt, egybeszabott, gömbölyű kivágású cigányruhát viselt, melynek szoknyája bő redőkben omlott le egészen a bokájáig. Ez a viselet, pénzérmékből összeállított ékszereivel együtt nagy feltünést keltett. ${ }^{87}$

85 Apja amerikai cigány volt, aki Londonban élt és ott egy polgári származású lányt vett el feleségül. Két lányuk született, az idösebbik volt Fenella.

86 Horváth J. 1995, 54.

87 Uo. 
Abban a közel egy évben Rippl-Rónai kimeríthetetlen lelkesedéssel alkalmazta Fenellát modellként (14. ábra). Arca csúnyasága miatt portré egy sem készült róla, ellenben „tiszta görög szobor aktja volt”. ${ }^{88}$ „Piktúrámban van egy egész hosszú és lázas Lazarinekorszak. Rajta kívül még csak két modellel foglalkoztam kimeritően. Az egyik fogadott leányunk volt, Anella, feleségem húgának gyermeke, akit kicsi kora óta mi neveltünk... A harmadik modell, aki nagyon érdekelt, az Fenella volt." évben igen meghatározó lett a Róma-villa életében. Zenei képzettsége és a zenéhez való ragaszkodása nagyban hozzájárult a zenei élet fellendüléséhez. A zenének köszönhette Rippl-Rónai, hogy megismerte, az volt az, ami felkeltette az érdeklődését Fenella személye iránt.

Ahogy az 1910-es évekre átalakult Rippl-Rónai festészete, melyben a vad színek és még erősebb kontúrok képezik a kompozícióit, úgy nyilvánul meg új felfogásmódja grafikáin is. ${ }^{90} \mathrm{~A}$ kontúr, amely a kukoricás képeken a vad színek mellett továbbra is nagyon fontos szereppel bír, új vonalstílust eredményez, mely grafikáiban is megjelenik. Ugyanakkor grafikáiban tematikai változás is tetten érhető. Míg festményein ritkábban találkozunk aktos kompozícióval, ${ }^{91}$ grafikáiban azonban számos aktot találunk, modelljei sokszor felismerhető személyek, és olykor erotikus töltettel is bírnak hanyag, néha kihívó testtartásaik. ${ }^{92}$ Fenella meghozta Rippl-Rónai munkakedvét, „,hogy róla képeket és rajzokat készítsen. Alig múlt el nap azon a nyáron, hogy Fenella ne állt volna modellt" - emlékezik Anella. Az ősz bekövetkeztével „már a lakásban folytatódtak az ülések”, s ettől kezdve már csak rajzok készültek. ${ }^{93}$ Az ekkoriban készült tusrajzok elképesztő spontaneitással ragadnak meg egy-egy pillanatot vagy mozdulatot. Rippl-Rónai vonalstílusa ekkoriban vastag, szálkás, kusza kontúrokat rejt magában, amelyek időnként felülírják egymást, hangsúlyozva a véglegest, amely mellett a korábbi vonalak is láthatóak maradnak. ${ }^{94} \mathrm{Ez}$ az új festői stílusából táplálkozó új vonalstílus hozzájárult a spontaneitás kifejezéséhez, amelyet ezeken a tus vagy tollrajzokon leggyakrabban a lúdtoll használatával ért el. ${ }^{95}$

88 Dénes Zsófia: Rippl-Rónai. - A Reggel 1926. aug. 2. Közli: Bernáth M. 1998, 164.

89 Uo.

90 „Ma, - ideges vagyok a szemem, lelkem kívánja a kedély életet - erös színeket, határozott körvonalakat. Azt szeretem ma, ha képeimen a színek toborzékolnának [sic!] ha orgiát üznek és végül jól összeházasodnak, egy nagy színharmóniába fulladnak bele." Levél Rónai Jánoshoz (Kaposvár, 1910. okt. 8.). Közölve: Rippl 1998, 507.

91 Aktos kompozíciói legtöbbször elvont tartalmúak vagy egy nagyobb szabású mü tervei. PI. Park aktokkal (1911-12); Modelljeim kaposvári kertemben (1911); Festés közben. Három meztelen nöi alak (1911) Ld. Rippl 1998, 346-350. (Kat. 106-107.) Vö. Passuth K. 2005, 188.

92 Passuth K. 2005, 188

93 Horváth J. 1995, 55

94 Ld. Gombosi György Rippl-Rónai rajzairól. - In: Gombosi Gy. 1984, 19.

95 „A tollrajz spontaneitása a vonal mentén kiszáradt tinta irizáló foltjainak vaskosságából fakad.” Rippl 1998, 441. (Kat. 190.); Ld. még: Horváth J. 1995, 55

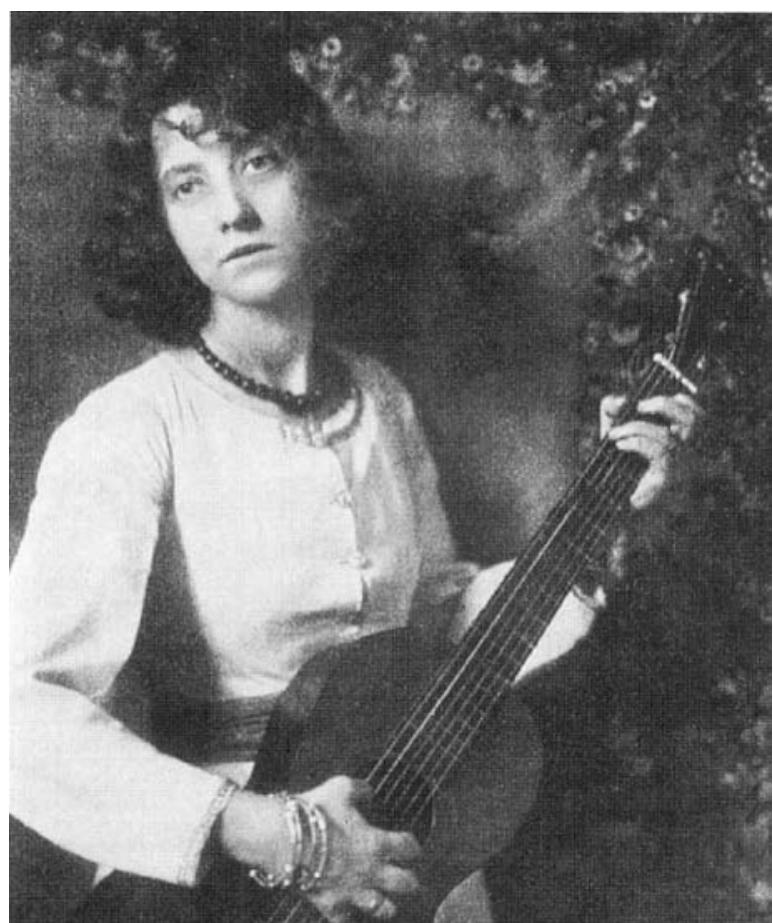

14. ábra. Fenella Lowell, 1910. Máté Olga felvétele

A Fenelláról készült rajzok is több tematikai csoportra oszthatóak. Aktrajzokon túl gyakran zenei utalású spontán pillanatokat is megörökített. Az utóbbiakon a felöltözött Fenella legtöbbször gitározik, miközben énekel (1521., 26. ábrák). Érdekes a modell-cigánylány társadalmi státusza, amely ezek fényében is némiképp eltér a korban általános aktmodellek társadalmi szerepétöl. A 19. század közepétöl kezdve a festőmodellnek álló hölgyek társadalmi helyzete és erkölcsi megítélése a prostituáltakéhoz volt hasonló, akiket a szükség és kényszer küldött a festőállvány mögé, $s$ akiket ez a kiszolgáltatottság taszított a társadalmi hierarchia legaljára. Ezek között azonban akadtak kivételek, s Fenellát is azok közé kell sorolnunk, akik nem jobb híján maradtak a modellkedés mellett. ${ }^{96}$ Fenella független nő volt, aki müvészi ambícióival hamar a figyelem középpontjába került, s műveltségét Rippl-Rónai is elismerte, aki nemcsak modellként alkalmazta, hanem művészi törekvéseiben támogatójává is vált. Azontúl, hogy ideális modellnek számított az egzotikumok iránt fogékony korban, extravagáns személyiségével magát a festőt is lebilincselte, aki felismerte a csak őt jellemző különlegességeket, s ezeket hagyta kifejezésre jutni művészetében is. Így a különleges öltözetében megjelenő gitározó hölgy egy különös tematikát tár a néző elé, amelyben a zene hatása alatt álló müvész képét ismerhetjük fel. Ennek az elmélyültségnek az ábrázolása nem idegen a kor zenei képtémái között, amelyben a zene hatalma és lebilincselő hatása egy képbe süritésben nyer kifejezést. A jól megválasztott pillanat képes kifejezni egy egész folyamatot, egy olyan lendüle-

96 Berecz Á. 2004, 175-181. (178.) 


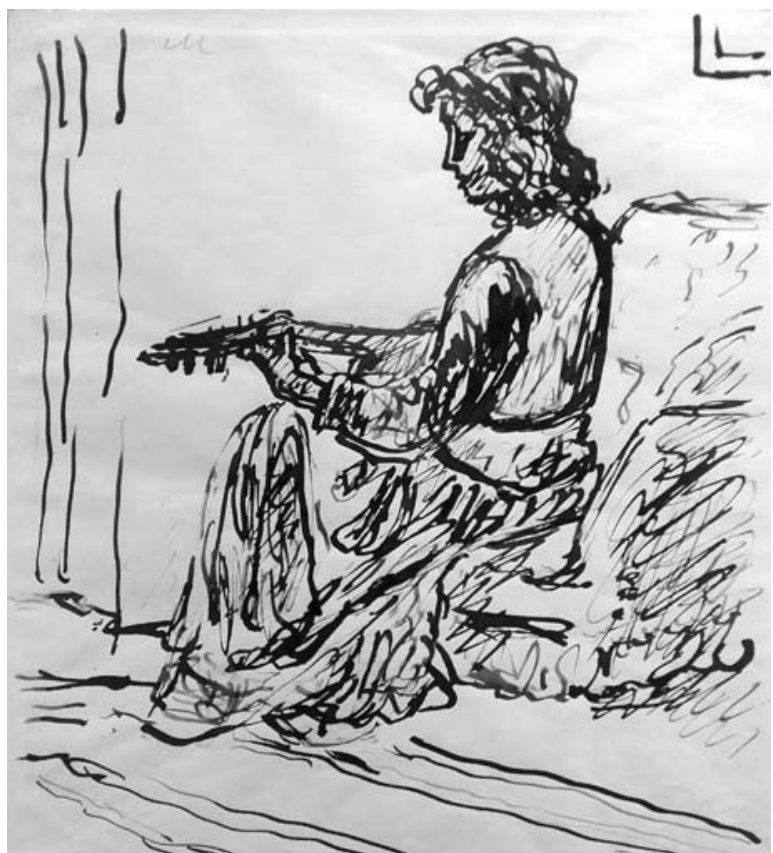

15. ábra. Rippl-Rónai József: Gitározó nő, 1910.

Tusrajz, toll, papír; 288 × 229 mm; Budapest, Magyar Nemzeti Galéria, Grafikai Osztály, Ltsz. 1911-343

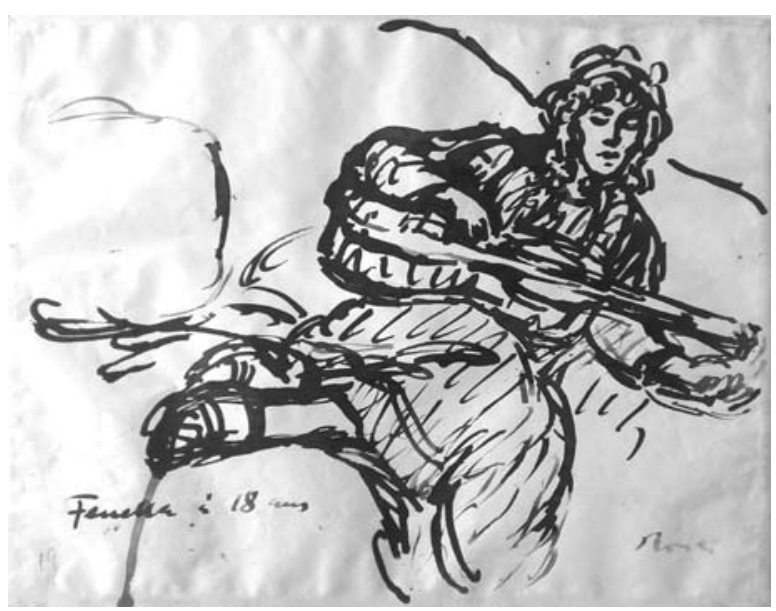

17. ábra. Rippl-Rónai József: Fenella 18 éves (Fenella à 18 ans), 1910. Tusrajz, toll, papír 230 x $288 \mathrm{~mm}$; Budapest, Magyar Nemzeti Galéria, Grafikai Osztály, Ltsz. 1930-2179

tet, amely kiemeli a képet az állókép mozdulatlanságából és dermedtségéből. Rippl-Rónai ilyen pillanatokat örökít meg a Fenella rajzokban, ahol a zene erős jelenléte nyilvánul meg a nő különböző hangulataiban. A gitározó Fenella-képek sora a legszélsőségesebb érzelmeket mutatja meg a hölgy őszinte arckifejezéseiben, amelyek a zenei élményre vezetnek vissza. A nő olykor tudomást sem vesz a müvészröl, miközben gitárjával foglalatoskodik (Gitározó nö, Fenella 18 éves korában). Arcának vonásai némelyik képen egész kisimultak (19. ábra), míg máshol kifejezetten csúnya (21. ábra), néhol elmerülő melankolikus (20. ábra), máskor jókedvűen kacagó (18. ábra). A kompozíció is rendkívül spontán, a különböző

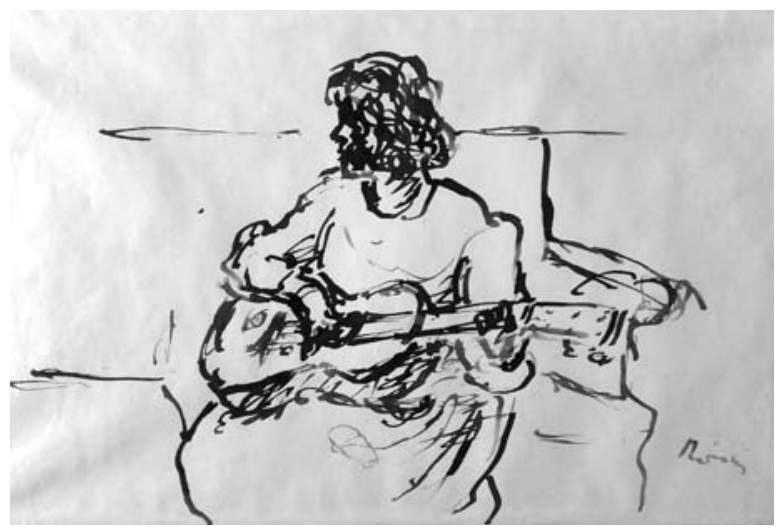

16. ábra. Rippl-Rónai József: Gitározó nő, 1910.

Tusrajz, toll, papír; 208 x 339 mm; Budapest, Magyar Nemzeti Galéria, Grafikai Osztály, Ltsz.1935-2830

szögekből ábrázolt zenész olykor hangszerének tartásával is kifejezi kedélyállapotát (18. ábra). Ezek a spontán elkapott pillanatok olyan hétköznapi jelenetek, melyek a beállított aktképek ellenpontjaiként szolgálhatnak.

Aktos kompozícióiba is gyakran vegyül zenei tartalom, melynek legérdekesebb példái a zeneszerszámát hanyagul hátrahagyó (de attól megszabadulni nem akaró) hátakt kompozíció (22. ábra), vagy a gitárját hangoló meztelen modell (23. ábra). Ezek mind arra engednek következtetni, hogy Rippl-Rónai tudomásul vette a lány szeszélyeit, s műveibe beépítette a modell zenétől elválaszthatatlan voltát. Fenella zenéhez és zeneszerszámaihoz ragaszkodó művészlelke így egy új képtípust eredményezett, mely Rippl-Rónai elfogadásából és müvészi kreativitásából született. A kaposvári Rippl-Rónai Múzeum az ilyen zenei kötődésű aktos kompozícióknak egy gyönyörü példáját őrzi, amelyen Fenella egy zongoraszéken ül, kezében pedig gitárját lógatja (27. ábra). Készült olyan tusrajz is, amelyen a pusztán aktmodellként megjelenő nőt egy - az ő személyéhez leginkább illő s a hozzá kapcsolható asszociációk legjobb kifejezőeszközéül szolgáló - zongora elé állította (24. ábra).

Ezeknek a grafikáknak egy része később bekerült az 1913-ban Rippl-Rónai ötven rajza (28. ábra) címen megjelent cinkográfiasorozatba is (16., 18., 27., 29., 37., 40., 43. számú rajzok). A kaposvári Rippl-Rónai Múzeum őriz még egy érdekes Fenella-képet, amely ezúttal vegyes technikájú (Gitározó nő) (25. ábra). A hölgy háttal ül az ablak előtt, $s$ a kép jobb felső sarkában hosszabb felirat áll: „O Luce di Quest'anima Donizetti”. A konkrét zenei utalás egyértelmü: Fenella Donizetti Linda di Chamounix című operájának egyik áriáját énekli. ${ }^{97} \mathrm{~A}$ feliratok jelentőségéről és szerepéről egy kicsit később kívánok szólni.

Rippl-Rónai valóban nemcsak modellként alkalmazta Fenellát. Különcségében, szeszélyeiben meglátta benne a múvészt, s támogatta őt abban, hogy ne csak a villa lakói ismerhessék meg tehetségét. A korabeli helyi sajtóból kiderül, hogy Rippl-Rónai nagyban hoz-

97 Ez a betétdal az első felvonás harmadik jelenetének kezdő áriájában kapott helyet, melyet a címszereplö énekel. A szövegkönyve Id. http://www.librettidopera.it/zpdf/lindacham.pdf (Utoljára letöltve: 2016. 04. 15. 10: 23) 

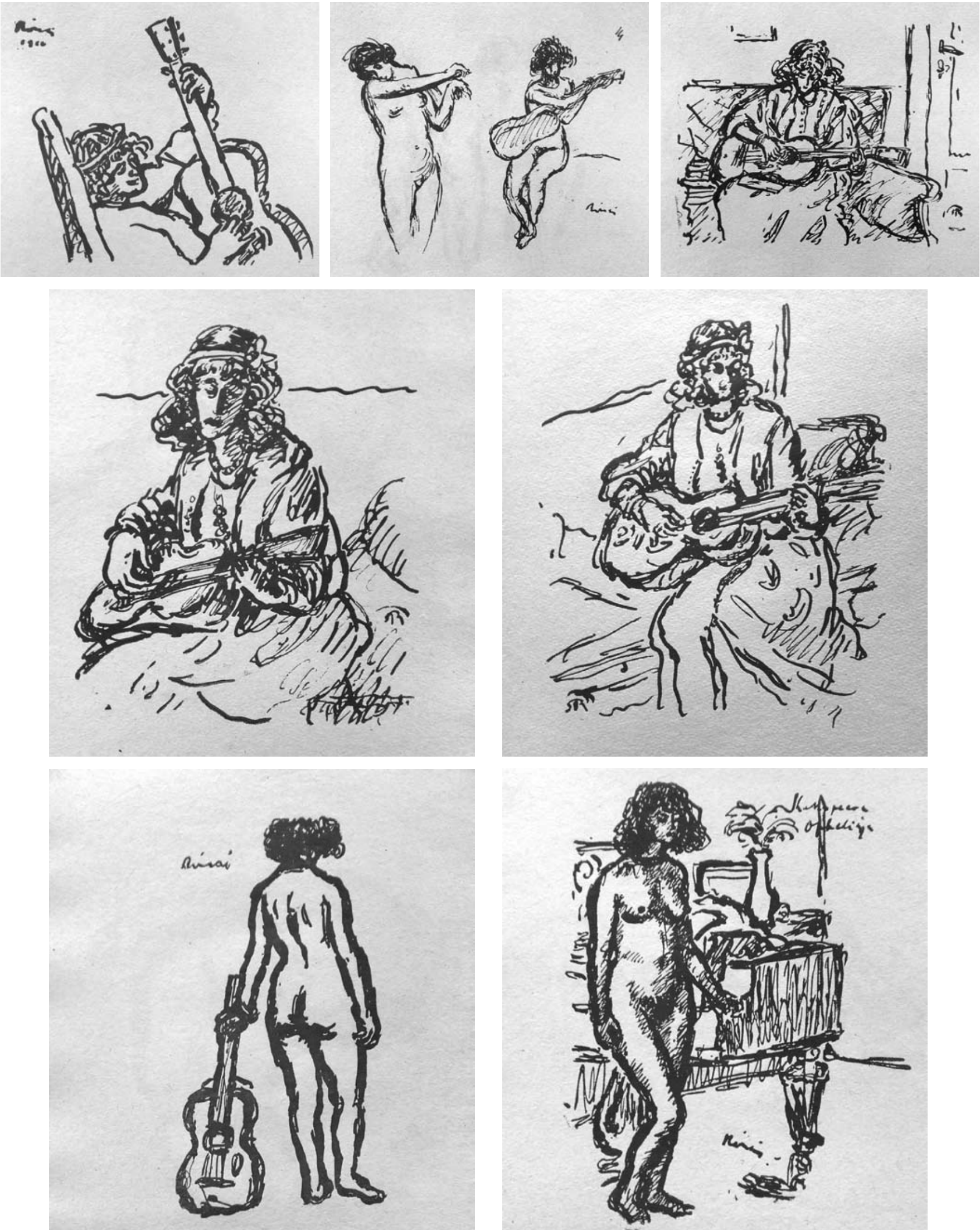

18-24. ábra. Rippl-Rónai ötven rajza, 1913. 45 db cinkográfia és 5 db ofszett reprodukció; 295 x 372 mm (29., 18., 43., 40., 27., 16., 37. számú rajzok) 


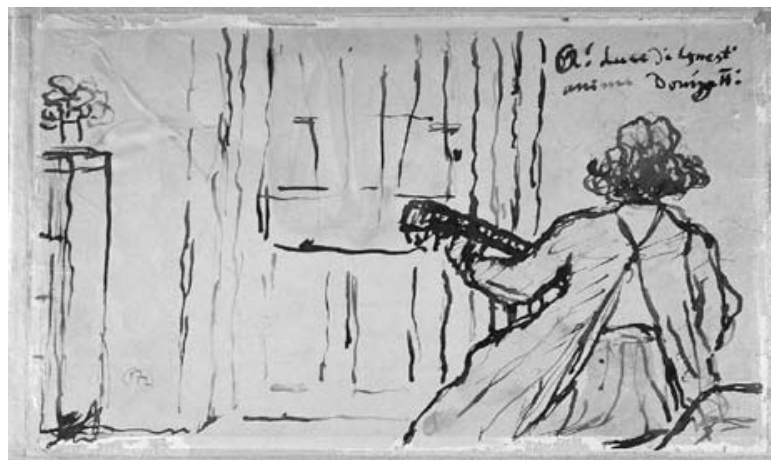

25. ábra. Rippl-Rónai József: Gitározó nő, 1910 körül. Vegyes technika, karton;

Kaposvár, Rippl-Rónai Múzeum, Ltsz. 55.051.

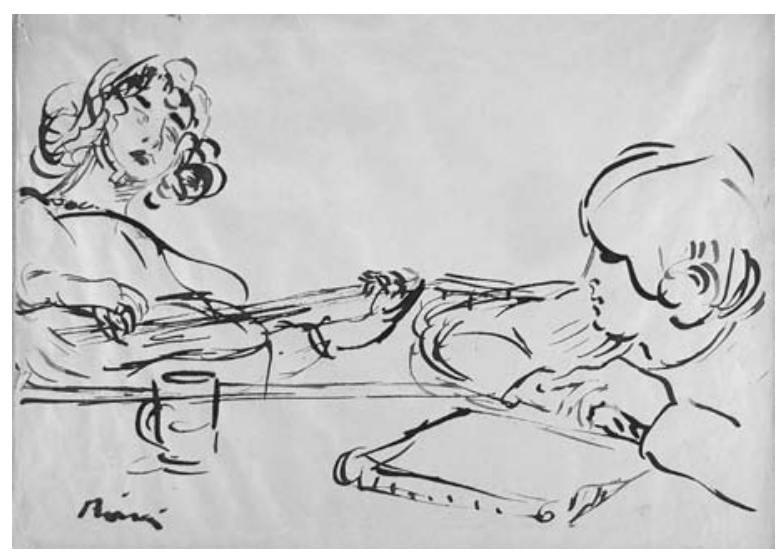

26. ábra. Rippl-Rónai József: Mandolinozó nő, 1910 körül. Tusrajz, papír; Kaposvár, Rippl-Rónai Múzeum, Ltsz. 75.5.1.1.

zájárult ahhoz, hogy Kaposváron fellendüljön nemcsak a képzőmüvészeti, hanem a zenei élet is. Fenella ott tartózkodása alatt lehetőséget teremtett arra, hogy az egzotikus művésznő a kaposváriak számára is zenei élménnyel szolgálhasson. Szervezésének köszönhetően 1910. október 27-én a kaposvári zenekedvelők hangversenyén Fenella is fellépett. A korabeli lapok a közönség elragadtatásáról számolnak be, s a cigánylány-pacsirtát a festő felfedezettjének titulálják. ${ }^{98}$ Maga Rippl-Rónai is büszke volt az eseményre, levelében Ödön öccsét is kéri, hogy okvetlenül jöjjön el a koncertet meghallgatni. ${ }^{99}$ Érzékletes a Somogyi Naplóban megjelent beszámolóban Fenella müsorszámainak leírása: „A dobogóra fölállítottak egy asztalt; papirosteritővel volt leboritva és egy virágcsokor pihent rajta. Piros teritős virágcsokros-asztal gitárral mellette egy kreolarcu fehérruhás leány és a háttérben a barna zongora fölé egy müvészkoponyáju ember hajlik... Képszerü, festményszerü volt az elrendezés. A kezdetleges diszletezések szinfoltokat alkottak, amelyek egy Rippl képet varázsoltak az ember szeme elé. És a közönség megértette a müvészetet. Sejtette, hogy itt

98 Somogyi Napló (1. évf.) 1910. 66. sz. (okt. 26.), 3.; Somogyi Napló (1. évf.) 1910. 69. sz. (okt. 29.), 2.

99 Levél Ödönhöz (Kaposvár, 1910. okt. 24.) MTA MKCS-C-I$36 / 606$

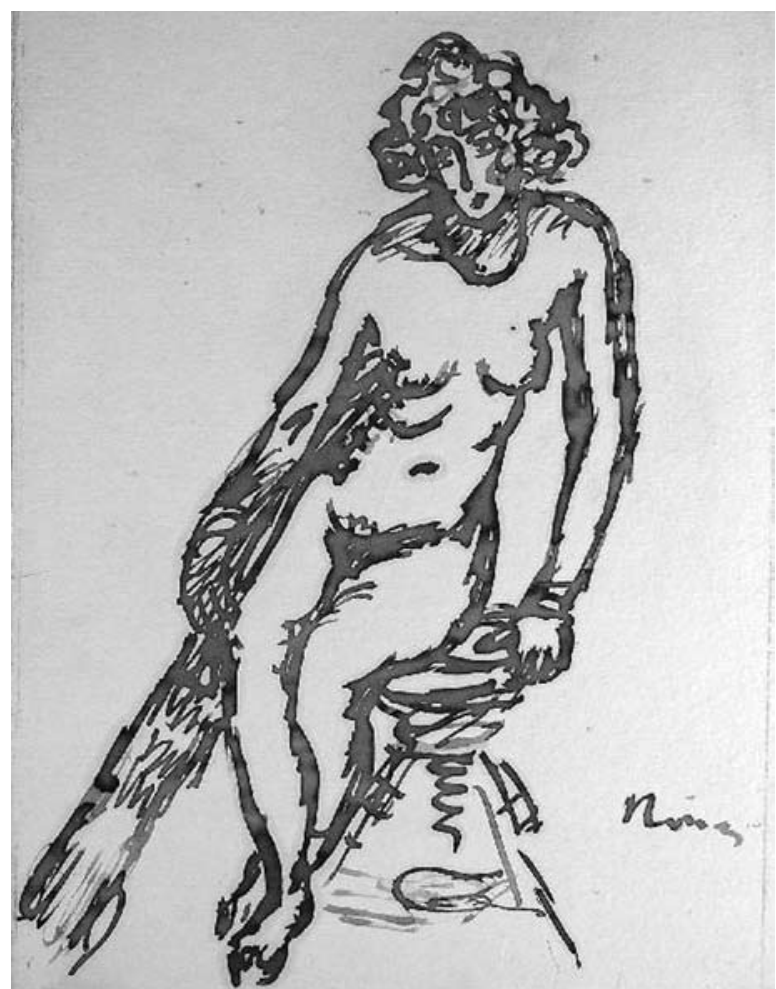

27. ábra. Rippl-Rónai József: Ülő akt, 1910 körül. Tusrajz, toll, papír; Kaposvár, Rippl-Rónai Múzeum, Ltsz. 55.079.

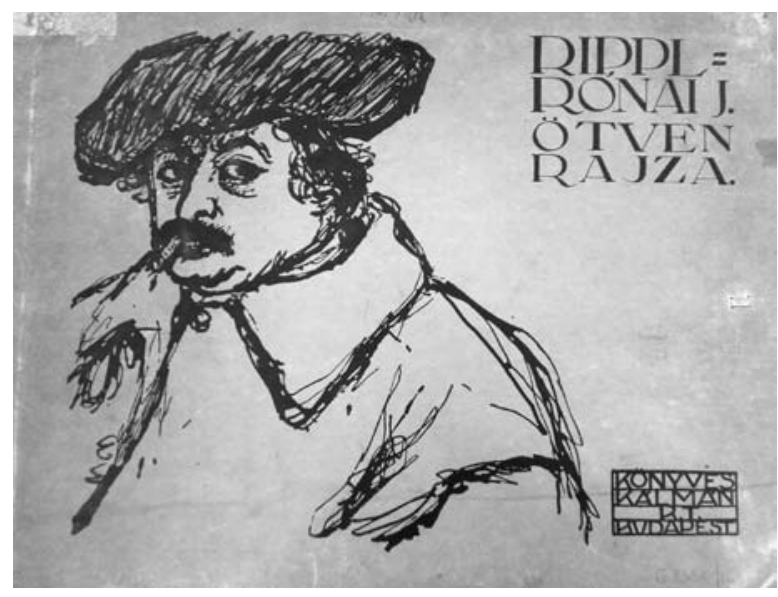

28. ábra. Rippl-Rónai ötven rajza, 1913. Címlap. $45 \mathrm{db}$ cinkográfia és 5 db ofszett reprodukció. 295 x 372 mm; Budapest, Magyar Nemzeti Galéria, Grafikai Osztály

Rippl-Rónai mester játszott közre. Lovell Fenella [sic!], az énekes cigányleányt, - akihez a koncert közönségének Rónai József festőmüvész utján volt szerencséje, mert ő hozta Párisból hozzánk - a mester vétette körül érdekes milliővel. A cigányleány és a milliője szemre hatott és az énekek, amelyek az ajkáról elhangzottak, megrészegitették a hallgatóságot. "100 Hasonló példá-

100 Somogyi Napló (1. évf.) 1910. 69. sz. (okt. 29.), 2 
kat látunk Vuillard enteriőrjeiben, ahol a zene szépen simul bele a környezetbe, ugyanakkor uralja a teret, s a képi ábrázolás a zenei tapasztalat kifejezését szolgálja. Rippl-Rónai is ezt kívánta megteremteni nemcsak otthonában, festményein, hanem a színpadon is, amely ismét a francia körök hatásáról árulkodik.

\section{További zenei jelenetek - a feliratok szerepe}

A korabeli kaposvári lapokból az is kiderül, hogy Fenellán túl ugyanazon a koncerten egy zongorista is újonnan lépett a közönség elé. Novák József, a kaposvári gimnázium tanára, Rippl-Rónai szerint „elsőrendű zongorista" volt, aki az októberi hangversenyen zongoratrió keretében, illetve szólóban is megmutatkozott. ${ }^{101}$ Anella emlékei szerint Novák gyakran és több éven át a Róma-villa vendége volt, kinek zongorajátékát délutánonként, sőt sokszor még vacsora után is örömmel hallgatták a villa lakói. ${ }^{102}$ Rippl-Rónai örömmel újságolta Ödönnek, hogy Novákra milyen nagy hatást tett Fenella zongorajátéka, a lány müvészi érzékére vonatkozó elismerés nyilván jól esett az őt felfedező és támogató mesternek. ${ }^{103}$ Fenella, akit orvosa gyenge fizikuma miatt eltanácsolt a zongorázástól, otthon gyakran csillogtatta meg zongoratudását legkedveltebb komponistái, Schumann, Chopin és Liszt müvein keresztül. ${ }^{104}$ Rippl-Rónai egy grafikája (Zongoránál, 1910) (31. ábra) két hölgyet ábrázol a zongoránál, akiknek beállítása Renoir a Lerolle-lányokról készült festményét juttathatja eszünkbe (Yvonne és Christine Lerolle a zongoránál, 1897). A zongorázó hölgy hajviselete Anella mindenkori hajviseletére emlékeztet, a lapozó hölgy pedig nem kizárt, hogy Fenella. Könnyen lehet, hogy a mester őket ábrázolta, hiszen Anella saját bevallásából tudjuk, hogy Fenellától ott tartózkodása alatt zongorázni is tanult. ${ }^{105}$

Novák zenei ízlése hasonló lehetett Fenelláéhoz, ugyanis - Grieg nevével kiegészítve - az elöbb említett zeneszerzőket kedvelte ő is, s Rippl-Rónai nagy valószínűséggel lehetőséget teremtett számára, hogy a koncertre készülvén napokon át gyakoroljon a villában. Ez az időszak Martyn Ferencre is nagy hatással volt, aki gyermekként Rippl-Rónai mellett segédkezett munkája során, és arról számol be, hogy a napi munka befejeztével a muzsika felcsendülése mindenki számára ünnepnek számított. Ő emlékezik meg egy fiatal zongoristáról, „aki koncertjére készült, és akit éppen emiatt láttak vendégül a Róma hegyen, Chopin mazurkákat és noktürnöket gyakorolt. Órákon át, egész nap, egyedül, magárahagyottan." ${ }^{106}$ Nem tudni, hogy ez az úr volt-e Novák, akiről tudomásunk van, hogy az októberi koncerten adott elő Chopin müveket, ${ }^{107}$ Martyn

101 Levél Ödönhöz (Kaposvár, 1910. okt. 24.) MTA MKCS-C-I-36/606; Somogyi Napló (1. évf.) 1910. 69. sz. (okt. 29.), 2.

102 Horváth J. 1995, 57.

103 Levél Ödönhöz (Kaposvár, 1910. okt. 24.) MTA MKCS-C-I$36 / 606$

104 Horváth J. 1995, 54

105 Uo., 55

106 Martyn F. 1979, 123

107 A Somogyi Napló tudósítója szerint Novák a koncerten más szerzők művei között Chopintöl egy etűdöt és az F-dúr prelúdiumot adta elő. Ld. Somogyi Napló (1. évf.) 1910. 69. sz. (okt. 29.), 2. azonban az ő személyéről külön is megemlékezik. ${ }^{108}$ Rippl-Rónai rajzai közt találunk több rajzot a zongorázó Novák Józsefröl is. Több ekkoriban készült rajz üres felületébe feliratot biggyesztett a mester, melyek ugyanazzal a tollal kerülnek a papírra, mint amellyel maga a kompozíció készül, fokozva ezzel a spontaneitás hatását. Több rajzán ezek a feliratok értékes információkat hordoznak a modellek kilétéről, valamint beillenek gyors - noteszbe illő - feljegyzéseknek. ${ }^{109}$ Más esetben azonban a rajzon megörökített pillanat hátterét világítják meg, mellyel a mű teljesebb megértéséhez is segítik a nézőt. Ilyen rajzok készültek Novákról is, akit két alkalommal azonos szögböl örökített meg a festő (29-30. ábra). Mindkét rajzon a felirat azonos megjelölést szolgál, a zongorista által a rajz készülésekor játszott mú címét jegyzi fel (egyik alkalommal az előadó nevével). Ezzel a néző számára is elhelyezi az ábrázolt pillanatot a megfelelő kontextusban. Az ilyen információk birtokában megvan a lehetősége annak, hogy a néző úgy tekintsen a müre, mint a zenei élmény és a zenemű befogadásának egy kiragadott pillanatára. Azzal, hogy Rippl ilyen „kísérőszöveget” ír müvéhez, egy olyan érdeklődést és igényt fejez ki, amely a 19. századtól kezdve több európai festőben megfogalmazódott; a zenei élmény időbeli és nem látható mivoltát látható és körülhatárolható formában kifejezni egy bizonyos pillanat megragadásában, amely az adott állapotot a legjobban kifejezi. Erre jó alkalma nyílt Novák jelenléte által, aki nagy valószínűséggel gyakorolhatta a koncerten játszott müveket - mivel a feliratokból az derül ki, hogy a kép készülésekor játszott darabok („Preludium Chopin” és „Magányos vándor Grieg") azonosak a hangversenyen előadott müvekkel -, így otthon több alkalommal nyílhatott lehetősége a darab meghallgatására és az abból fakadó zenei élmény tanulmányozására. A felirattal megjelöli a kép konkrét tárgyát, amelyben a zongorista portréján túl egy elmúló zenei élményt kíván megragadni, s azt a „modell” személyéhez kapcsolni.

Ehhez a tematikához, valamint a feliratok fontos szerepéröl tanúskodik még egy grafika, amely a Róma-villa zenei életét a hallgatók oldaláról is megmutatja. A tusrajz a következő címet, azaz feliratot hordozza a kompozíció részeként: Lajos, Margot, Fenella, Lazarine hallgatják Liszt rapszódiáját (1910) (32. ábra). Az amatőr hegedűs testvér, Lajos jelenik meg a társaság bal szélén, mellette felesége, Piatsek Margit. ${ }^{110}$ Jelen esetben azért fontos a feliratban a zenei utalás megje-

108 „Nem lévén villany, esténként két gyertya világánál hallgattam a zongorát; egy Novák nevezetü zongoramüvész Lisztet adott elö." Martyn F. 1979, 122.

$109 \mathrm{PI}$. Két akt kanapén ülve (1910-11), amelyen a modell testvérpár címe, neve és kora szerepel. Ld. Rippl 1998, 443. (Kat. 191.) Vö. Passuth K. 2005, 189. Hasonló feljegyzésnek, megjegyzésnek tünik a Fenella à 18 ans felirat a gitározó Fenella rajzon. (29. kép)

110 Elgondolkodtató, hogy a kép címében és feliratában miért Margot és miért nem a Margit név szerepel. Talán Rippl-Rónai kézírásának félreolvasásából fakadóan terjedt el ez a név, ugyanis a rajzot már 1935-ben ezen a címen állították ki a Szépművészeti Múzeumban, ekkor került ugyanis a múzeum gyűjteményébe. Ld. Rippl 1998, 446. (Kat. 196.) Genthon kéziratos oeuvre-katalógusában Margitot ír. Ld. MTA MKCS-C-I-36/3865 


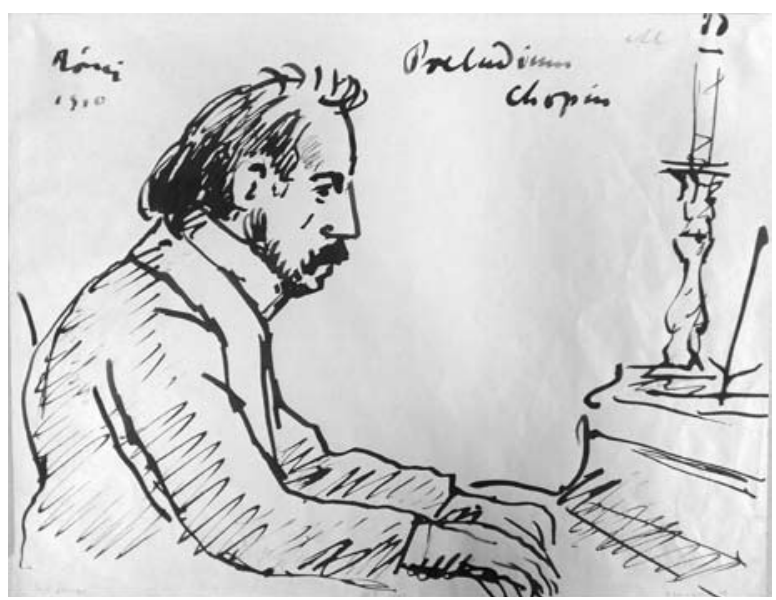

29. ábra. Rippl-Rónai József: Zongorista (Novák József) „Preludium Chopin”, 1910. Tusrajz, toll, papir; 229 × 289 mm; Budapest, Magyar Nemzeti Galéria, Grafikai Osztály, Ltsz. 1911-346

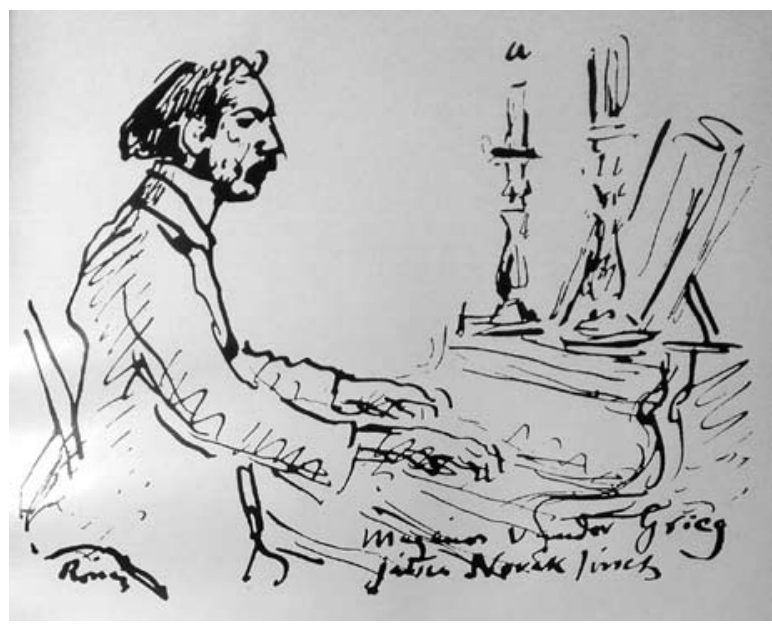

30. ábra. Rippl-Rónai József: Zongorista „Magányos vándor Grieg játsza Novák József”, 1910. Tus, papír; Magántulajdon

lölése, mert annak forrását, a zongoristát nem ábrázolta a festő. Ha hiányozna a cím, a néző hamar túllépne a grafika szemlélésén, mint egy hétköznapi pillanatot ábrázoló jeleneten. A cím azonban segít a tájékozódásban, s megállítja a nézőt, hogy jobban megvizsgálja a szereplőket. Ugyanis, amint Anne Leonard mondja, a zene ereje és gyengesége egyszerre nyilvánul meg az ilyen műveken. $A z$, hogy a kép szereplői zenét hallgatnak, nem mindig látható önmagában a képröl (ha a zene forrása nem jelenik meg), azonban feltételezzük, hogy a zene hallgatása megváltoztat valamit a szereplők arcán, megnyilvánulásán, ami kifejezi a zene erejét. Ezért fontos a cím, amennyiben csak az utal konkrétan a zenehallgatás tényére, mert anélkül nem biztos, hogy felfedezhető lenne az a változás, amely azonban jelen van, és a zenének köszönhetö. ${ }^{111}$ RipplRónai rátapintott erre, nagy valószínűséggel azt tanul-

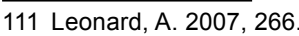

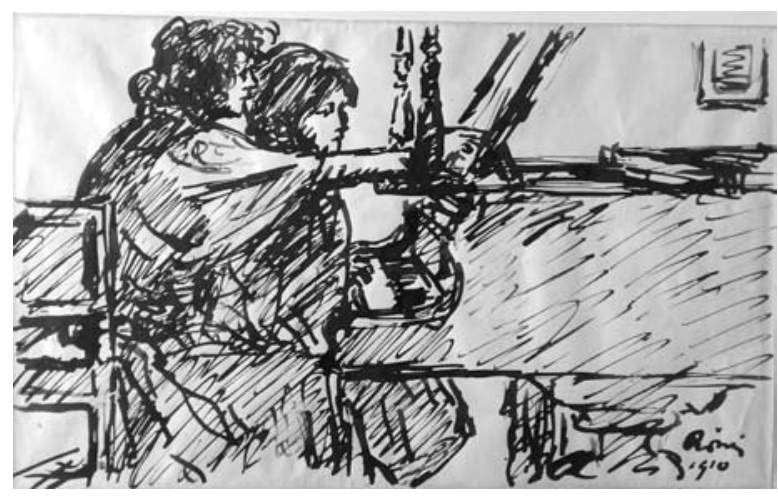

31. ábra. Rippl-Rónai József: Zongoránál, 1910. Tusrajz, toll, papír; 210 x 332 mm; Budapest, Magyar Nemzeti Galéria, Grafikai Osztály, Ltsz. 1935-2986

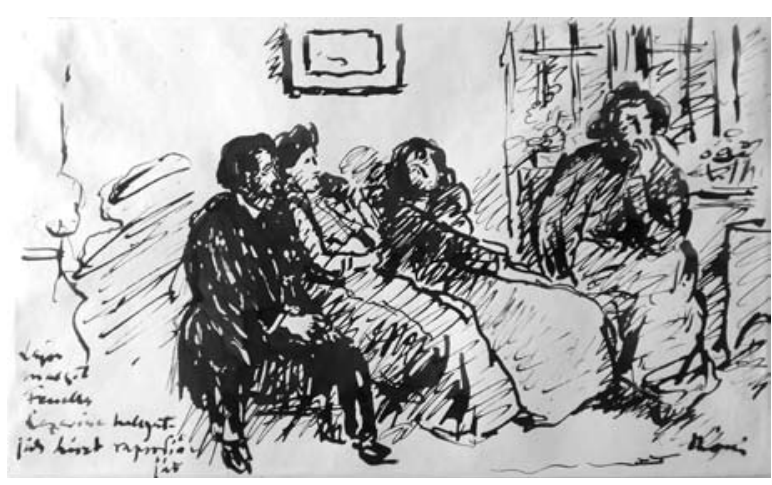

32. ábra. Rippl-Rónai József: Lajos, Margot, Fenella, Lazarine hallgatják Liszt rapszódiáját, 1910. Tusrajz, toll, papír; 208 x 338 mm; Budapest, Magyar Nemzeti Galéria, Grafikai Osztály, Ltsz. 1935-2821

mányozta, milyen hatással van a zene a hallgatókra, s ábrázolásukkal megpróbálta bevonni a kívülállókat is abba a miliőbe, abba a zenei élménybe, amelyben családja (és ő maga) részesült.

A hallgatókat önmagukban megjelenítő müvek viszonylag későn terjedtek el a festészetben, mivel mindig is egyszerübb volt a zenét megragadni a hangszeren játszó, zenei tevékenységet űző személyek ábrázolásán keresztül. Mégis a tisztán zenehallgatás megfestése éppen a 19. század végén kezdett érdekes feladattá válni, először a francia és a belga festők körében. Mint láttuk Ensornál (4. ábra) és Khnopff-nál (3. ábra), egyre inkább kiszorítja a hallgató a zenészt a képről, hogy a festő a zenei tapasztalatot a forrás ábrázolása nélkül is képes legyen megragadni. ${ }^{112}$ Ez kapcsolatban van azzal a változással, amely a 19. század folyamán a zenehallgatási szokásokban következett be, s amelyet korábban már kifejtettem. Rippl-Rónai villájában is ez az újfajta hozzáállás érhető tetten, mikor „áhitatos csendben, mozdulatlanul” hallgatták a muzsikát. ${ }^{113}$ Mivel a festő megtapasztalhatta Párizsban azt a légkört, amely a zenének ilyen kitüntetett szerepet szán, ennek hatása bizonyosan beépült művészi felfogásába.

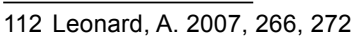

113 Martyn F. 1979, 122. 


\section{Összegzés}

Rippl-Rónai számára a zene igen kitüntetett helyet foglalt el, melyet nemcsak az 1910-es években egyszerre megnövekvő zenei témájú művei támasztják alá, hiszen szerepet vállalt a zenei élet fellendülésében is, egy-egy általa tehetségesnek vélt müvész támogatásában. Impulzusai a franciáktól származtak, az antiteátrális hagyományt folytató és egyben azt feszegető képei, az összművészetre való igény, a dekorativitás zenei kifejezőeszközként való alkalmazása mind a Nabik és a modern francia körökhöz való tartozást és visszacsatolást jelzik, éppúgy, mint a Róma-villában kialakított életforma. Itthon az 1910-es években az új zenei és képzőművészeti áramlatokhoz alkalmazkodva fejezi ki az ott elsajátított hozzáállást. Bár e tanulmány terjedelmi okokból nem tárgyalta Rippl hazai modern zenei irányzatok képviselöivel való kapcsolatát (mint ahogyan a magyar népzene iránti lelkesedését sem), zenei érdeklődésének ez az iránya sem utolsó szempont, különösen a Nyolcak hasonló tevékenységei mellett. E terület Rippl-Rónai esetében azonban még további kutatások tárgyát képezi (Bartók Béla, Weiner Leó és a Waldbauer-Kerpely vonósnégyes kapcsán), csakúgy, mint francia zenészbarátai kilétének meghatározása, a Natanson-körön kívül más körökhöz való tartozása, valamint további - csak a korabeli katalógusokból ismert - zenei témájú müvek beazonosítása.

\section{Irodalom}

AlPERS, S. 2000: Hű képet alkotni. Holland művészet a XVII. században (Elöszó: Németh I.). Budapest

BAUDELAIRE, CH. 2001: Richard Wagner és a Tannhäuser Párizsban. - In: Egy német muzsikus Párizsban; Richard Wagner és a Tannhäuser Párizsban. (ford. Cserna A. és Lenkei J.). Budapest, 81-129.

BERNÁTH M. 1998: Rippl-Rónai József. Budapest

BERECZ Á. 2004: Egy bizarr délután. - In: MNG 2004, 175-181.

BEYOND THE EASEL 2001: Beyond the easel: Decorative painting by Bonnard, Vuillard, Denis, and Roussel, 1890-1930. (ed. Groom, G.) Exhibition catalogue. New Haven and London

BonNARD. (Ausstellung von Baumann, F., Stoos, T.; Katalog von Matta M.; Text von Clair, J., Perucchi-Petri, U. et al.). Ausstellungskatalog. Kunsthaus Zürich, 1984

Boros J. 2005: Egy magyar festő Párizsban. Munkácsy Mihály pályája 1870 és 1896 között. - In: Munkácsy a nagyvilágban. Munkácsy Mihály művei külföldi és magyar magán- és közgyűjteményekben. (kat. szerk. Gosztonyi F.). A Magyar Nemzeti Galéria kiállítási katalógusa. Budapest, 33-60.

BROCKHAUS RIEMANN: Brockhaus Riemann zenei lexikon (szerk. Dahlhaus, C., Eggebrecht, H. H., a magyar kiadást szerk. Boronkay A.). Budapest, (1. kötet) 1983; (2. kötet) 1984; (3. kötet) 1985

E. Csorba Cs. 1998: Elöhívás. Rippl-Rónai József és a fényképezés. - In: Rippl 1998, 185-199.

DENIS, M. 1983: A szimbolizmustól a klasszicizmusig. Maurice Denis elméleti írásai. (szerk. és a bev. írta: Revault d'Allonnes, O.). Budapest

EMLÉKEZÉSEK 1957: Rippl-Rónai József emlékezései, Beck Ö. Fülöp emlékezései (szerk. Farkas Z.). Budapest

FARMER, J. D. 1976: Ensor. Exhibition Catalogue. New York

FöLDI E. 2014: „Gyorsan elszaladt ifjúságunk.” Rippl-Rónai József és Aristide Maillol barátsága. - In: Rippl-Rónai és Maillol - Egy müvészbarátság története. A Magyar Nemzeti Galéria kiállítási katalógusa. Budapest, 9-75.

FRÉCHES-THORY C. 1998: Bonnard, Vuillard, Maurice Denis, Sérusier, Vallotton... Nabis, 1888-1900. - In: Francia szimbolisták: Gauguin, Pont-Aven, Nabis. (szerk. Gergely M. és Jávor A.). A Magyar Nemzeti Galéria kiállítási katalógusa. Budapest, 9-16.

FRIED M. 1980: Absorption and Theatricality. Painting and Beholder in the Age of Diderot. Chicago

FRIED M. 1998: Manet's modernism. Or, the face of painting in the 1860s. Chicago

GeLLÉR K. 1975: Bonnard. Budapest

GENTHON I. 1969: Rippl-Rónai kiadatlan levelei. - In: Képzőművészeti almanach 1. Budapest, 131-149.

GomBosı Gy. 1984: Új magyar rajzművészet Rippl-Rónaitól Vajdáig Emlékezés Gombosi György művészettörténészre. Budapest

HALMY F. - ZIPERNovszKY M. 1976: Hubay Jenő (Gertler E. előszavával). Budapest

HoRVÁtH J. 1998: A Róma-villa egykor és ma. - In: Rippl 1998, 167-173. HoRVÁTH J. 1995: Rippl-Rónai emlékkönyv. Paris Anella visszaemlékeZÉSEI RIPPL-RÓNAI JóZSEFRŐL. KAPOSVÁR

HORVÁTH J. 2007: Rippl-Rónai. Debrecen
KHNOPFF 2004: Fernand Khnopff (1858-1921). (ed. Devisscher, H. with Marechal, D., Leen, F. and van Vliet, S. et al.). Exhibition Catalogue of the Royal Museums of Fine Art of Belgium. Brussels

KESERÜ K. 2004: Neuillyben Rippl-Rónai József és James Pitcairn Knowles. Az Ernst Múzeum kiállítási katalógusa. Budapest

Leonard, A. 2007: Picturing Listening in the Late Nineteenth Century. The Art Bulletin Vol. 89. No. 2, 266-286.

LESSING, G. E. 1999: Laokoón; Hamburgi dramaturgia (vál. és jegyzetekkel ellátta: Balázs I.). Budapest, 7-150

Malonyay D. 1906: Rippl-Rónai József. - In: A fiatalok. Ferenczy Károly, Grünwald Béla, Katona Nándor, Magyar-Mannheimer Gusztáv, Rippl-Rónai József. Budapest, 180-220.

MARTYN F. 1979: Töredékek. Pécs

MNG 2004: Imre Gy. (szerk.): A modell. Női akt a 19. századi magyar müvészetben. A Magyar Nemzeti Galéria kiálítási katalógusa. Budapest

Mojzer M. 1967: Holland életképek. Budapest

MoLNOS P. 2007: Rippl a Vadak között - Egy magyar kép Houstonban. - Artmagazin 5. évf. 3. sz., 32-33.

MoReHEAD, A. 2007: A Certain tour d'Esprit: Édouard Vuillard's The Lerolle Salon. - In: Looking and Listening in Nineteenth-Century France (ed. Ward, M. and Leonard, A.). Smart Museum of Art. University of Chicago, 73-81.

MoRTon M. L. 2000: „From the Other Side”: An Introduction. - In: The Arts Entwined. Music and Painting in the Nineteenth Century. (eds. Morton, M. L. and Schmunk, P. L.). New York \& London, 1-21.

MTA MKCS-C-I-36: Genthon István hagyatéka az MTA BTK Művészettörténeti Kutatóintézet Adattárában

NATANSON 1994: Festőportrék. Szemelvények a Revue blanche festői c. részből. (bev. és ford.: Siklós Z.). - In: Somogyi Múzeumok Közleményei 10. Kaposvár, 253-260.

PANDUR J. 1985: Muzsika Rippl-Rónai József házában. - Somogy 6. Sz., 57-61.

PAssuth K. 2005: Fragmentum és egész. Rippl-Rónai Album. - In: András E. (szerk.): Angyalokra szükség van. Tanulmányok Bernáth Mária tiszteletére. Budapest, 183-192.

Petrovics E. 1912: Rippl-Rónai József otthon. - Vasárnapi Ujság 59. évf. 39. sz. (szept. 29.), 777-783.

RIPPL 1998: Bernáth Mária és Nagy lldikó (szerk.): Rippl-Rónai József gyüjteményes kiállítása. A Magyar Nemzeti Galéria kiállítási katalógusa. Budapest

SOMOGYI NAPLó (1. évf.) 1910. 66. sz. (okt. 26.), 3.

SOMOGYI NAPLó (1. évf.) 1910. 69. sz. (okt. 29.), 2.

SzINYEI MERSE A. 1999: Ami a budapesti, párizsi és frankfurti katalógusokból kimaradt... Rippl-Rónai József párizsi korszakának rejtőzködő kincseiből. - Magyar Művészeti Fórum II. évf. 4. sz. (aug.), 2-8.

SZINYEI MERSE A. 1998: Rippl-Rónai Franciaországban és kapcsolata a Nabis-csoporttal. - In: Rippl 1998, 49-68.

VAUGHAN, G. 1984: Maurice Denis and the Sense of Music. - Oxford Art Journal Vol. 7. No. 1, 38-48.

VUILLARD 2003: Édouard Vuillard. (Copublished by Cogeval, G. with Jones, K., des Cars, L., Stevens, M. A.). Exhibition Catalogue of National Gallery of Art. Washington 